\title{
Regulation of Antitumor Immune Responses by Exosomes Derived from Tumor and Immune Cells
}

\author{
Andrés Rincón-Riveros ${ }^{1}$ (D), Liliana Lopez ${ }^{2}$, Victoria E Villegas ${ }^{3}$ (D) and Josefa Antonia Rodriguez ${ }^{4, *(D)}$ \\ 1 Bioinformatics and Systems Biology Group, Institute for Genetics, Universidad Nacional de Colombia, \\ Bogotá 111321, Colombia; warinconr@unal.edu.co \\ 2 Department of Statistics, Universidad Nacional de Colombia, Bogotá 111321, Colombia; llopezk@unal.edu.co \\ 3 Biology Program, Faculty of Natural Sciences, Universidad del Rosario, Bogotá 111221, Colombia; \\ victoria.villegas@urosario.edu.co \\ 4 Research Group in Cancer Biology, Instituto Nacional de Cancerología, Bogotá 111511, Colombia \\ * Correspondence: jrodriguez@cancer.gov.co
}

check for updates

Citation: Rincón-Riveros, A.; Lopez, L.; Villegas, V.; Antonia Rodriguez, J. Regulation of Antitumor Immune Responses by Exosomes Derived from Tumor and Immune Cells. Cancers 2021, 13, 847. https:// doi.org/10.3390/cancers13040847

Received: 23 November 2020

Accepted: 14 January 2021

Published: 17 February 2021

Publisher's Note: MDPI stays neutral with regard to jurisdictional claims in published maps and institutional affiliations.

Copyright: (c) 2021 by the authors. Licensee MDPI, Basel, Switzerland. This article is an open access article distributed under the terms and conditions of the Creative Commons Attribution (CC BY) license (https:// creativecommons.org/licenses/by/ $4.0 /)$.
Simple Summary: A lot of interest has been placed into extracellular vesicles as an intercellular communication mechanism with potential clinical application. As these vesicles are found naturally in body fluids such as blood, urine and saliva, it is possible to isolate them from a liquid biopsy to analyze their content, elucidate their interaction with different cell populations (crosstalk) and determine their effect during the development of a particular pathology. Clinical applications of exosomes include the discovery of diagnostic or prognostic biomarkers for cancer and other diseases, and therapeutic approaches such as organ-specific delivery of drugs, among others. Here, we provide a specific review of how extracellular vesicles, such as exosomes, are carriers for biomolecules like immune checkpoint proteins, ligands, receptors and a wide range of RNA species, which can have an impact on cancer development.

Abstract: Exosomes are lipid membrane-enclosed vesicles released by all cell types that act at the paracrine or endocrine level to favor cell differentiation, tissue homeostasis, organ remodeling and immune regulation. Their biosynthesis begins with a cell membrane invagination which generates an early endosome that matures to a late endosome. By inward budding of the late endosome membrane, a multivesicular body (MVB) with intraluminal vesicles (ILVs) is generated. The fusion of MVBs with the plasma membrane releases ILVs into the extracellular space as exosomes, ranging in size from 30 to $100 \mathrm{~nm}$ in diameter. The bilipid exosome membrane is rich in cholesterol, ceramides and phosphatidylserine and can be loaded with DNA, RNA, microRNAs, proteins and lipids. It has been demonstrated that exosome secretion is a common mechanism used by the tumor to generate an immunosuppressive microenvironment that favors cancer development and progression, allowing tumor escape from immune control. Due to their ability to transport proteins, lipids and nucleic acids from the cell that gave rise to them, exosomes can be used as a source of biomarkers with great potential for clinical applications in diagnostic, prognostic or therapeutic areas. This article will review the latest research findings on exosomes and their contribution to cancer development.

Keywords: extracellular vesicles; exosomes; cancer; immunology

\section{Introduction}

During the last decades, great interest has arisen in the study of the alternative routes of cellular communication, a cell function essential for multicellular organisms to maintain homeostasis, particularly those mediated by the release of extracellular vesicles. These vesicles, secreted by most of the nucleated cells, are formed by a lipid bilayer and, according to their size, are classified as: (i) exosomes, of endocytic origin, with a diameter of 50-100 nm; (ii) microvesicles, formed by external budding of the plasma membrane, 
with a diameter of $100-1000 \mathrm{~nm}$; (iii) apoptotic bodies, formed by membrane blebbing of an apoptotic cell, with a diameter greater than $500 \mathrm{~nm}$ [1].

Exosomes are nanosized vesicles released into the extracellular space upon fusion of MVBs with the plasma membrane [2]. They were first described in studies of rat reticulocyte differentiation and later in human B-lymphocytes and dendritic cells (DCs) [3] Released exosomes can influence the activity of neighboring cells (paracrine action), travel to different sites in the body through the bloodstream (endocrine action) and be found in body fluids, such as urine, plasma, breast milk, nasal discharge and cerebrospinal fluid. Pathologically, they are found in ascites, bronchial washings and pleural effusions among others $[4,5]$.

Initially, it was believed that extracellular vesicles were a mechanism to remove cellular waste resulting from cell metabolism or damage, but exosomes play essential roles as vehicles for intercellular communication with specific targets [2]. They were shown to carry cell-specific cargos of proteins, lipids and nucleic acids, and can be selectively taken up by neighboring or distant cells. Released exosomes, upon contact with their target cells, may be internalized by pinocytosis or by endocytic receptors and can go into the lysosome for degradation. However, they can also mediate cell- cell interactions by binding the target cell membrane and directly activating cell membrane receptors, or by reaching specific cellular compartments to release their intraluminal material, thus transferring proteins from the lipid bilayer to the membrane of the target cellular compartment [6,7].

Exosomes exhibit different interactions with the immune system. Under normal conditions, they take part in antigen presentation and immune activation, whereas, in pathologic conditions such as cancer, they act as an immune evasion mechanism during tumor development, supporting crosstalk between cancer and immune cells [8].

\section{Exosome Biogenesis}

Exosomes are generated from late endosome membrane by an unconventional inward budding that results in the creation of large MVBs that act as a sorting platform for membrane proteins to develop ILVs loaded by the endosomal sorting complex required for transport (ESCRT) [9]. ILVs may follow one of three destinations: (i) if MVBs fuse with lysosomes, they are degraded; (ii) they could contribute to the development of specialized organelles such as melanosomes [10]; (iii) if the MVBs fuse with the plasma membrane, ILVs are secreted as exosomes into the extracellular milieu [11].

Several lipids and lipid metabolizing enzymes are involved in the formation and release of exosomes. Ceramide micro domains in areas with high sphingolipid concentrations are able to bind and generate large ceramide-rich domains to promote membrane budding $[12,13]$. Although the mechanism by which molecules are charged in exosomes is not clear, it is known that heparan sulfate proteoglycans, especially syndecans and their cytoskeleton coupling proteins, syntenins, appear to be involved in inducing intraluminal budding of the endosome membrane. The syntenin exosomes depend on the availability of heparan sulfate, syndecans, ALG2 interaction protein X (ALIX) and the endosomal classification complex required for transport (ESCRT) [14], which regulates the germination of the membrane on the cell surface and in the late endosome.

Loading molecules in the ILVs and exosome release from the endosomal membrane are mediated by two pathways: an endosomal sorting complex required for transport (ESCRT)-dependent pathway [15] and an ESCRT-independent pathway [16]. The ESCRT pathway comprises five different protein complexes (ESCRTs -0, -I, -II, and -III, and Vps4), capable of recognizing and classifying ubiquitinated load. ESCRT proteins are involved in the sequestration and classification of ubiquitous membrane proteins to deform the endosomal boundary membrane inward and generate the MVBs, while the Vps4 complex is needed to deliver the load to the vesicle (Figure 1) [17]. 


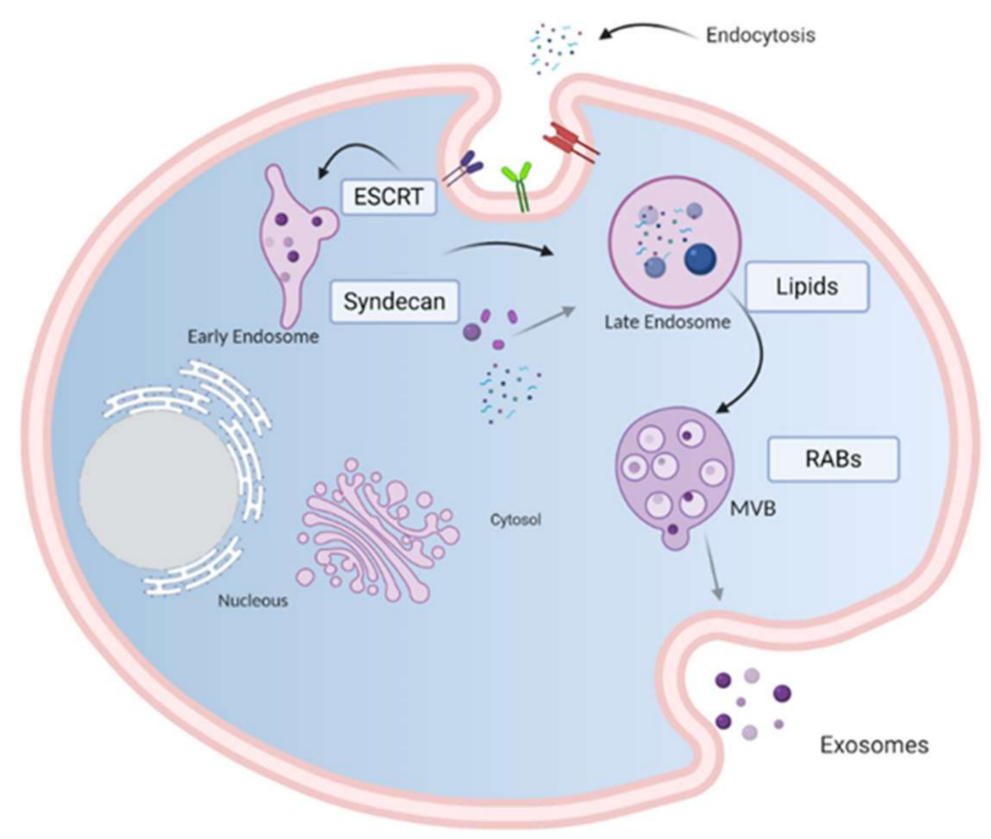

Figure 1. Model of biogenesis and release of exosomes. Cell-surface proteins and soluble molecules from the extracellular milieu enter cytoplasm by endocytosis or by plasma membrane invagination that results, at the luminal side of the cell, in the early-sorting endosome development which matures in a late-sorting endosome. Eventually, this late endosome generates a MVB by inward invagination of the endosomal membrane. This double invagination of the plasma membrane results in a MVB containing several ILVs. The MVBs can fuse with lysosomes where their cargo is degraded or can dock on the luminal side of the plasma membrane and merge with the plasma membrane to release the contained ILVs as exosomes. Rab GTPases, ESCRT, CD9, CD81, CD63, TSG101, ceramide, and Alix are involved in exosome biogenesis. Tetraspanins, integrins, sphingomyelinase, ceramides and immunomodulatory proteins are exosome surface proteins. The molecular exosomes' cargo is composed of cell surface proteins, intracellular proteins, RNA, DNA, amino acids, and metabolites. Image created with biorender.com.

\section{General Composition of Exosomes}

Exosomes from multiple organisms harbor more than 4500 proteins, 200 lipids, $1600 \mathrm{mRNAs}$ and $800 \mathrm{miRNAs}$ [18]. They are present in bodily fluids and interact with adjacent cells inducing a variety of downstream effects which depend on the cell type from which they are derived and on their load-bearing molecules (membrane and cytosolic proteins, lipids, mRNA and miRNA). The composition of exosomes varies depending on the originating cell type. In general, they are surrounded by a lipid bilayer enriched with sphingomyelin, phosphatidylserine, GM3 ganglioside, phosphatidylethanolamine, MVB-specific LBPA, and GPI coupled proteins such as CD55 and CD59. Other common constituents of exosomes are tetraspanins (CD81, CD63, CD9), heat shock proteins (HSP60, HSP70, HSP90) and MHC I/II antigens. Annexins regulate cytoskeleton and cell membrane fusion, Rab proteins control the exosome secretion pathway, and GTPases favor coupling and fusion between membranes and ESCRT proteins [19,20] (Figure 2). 


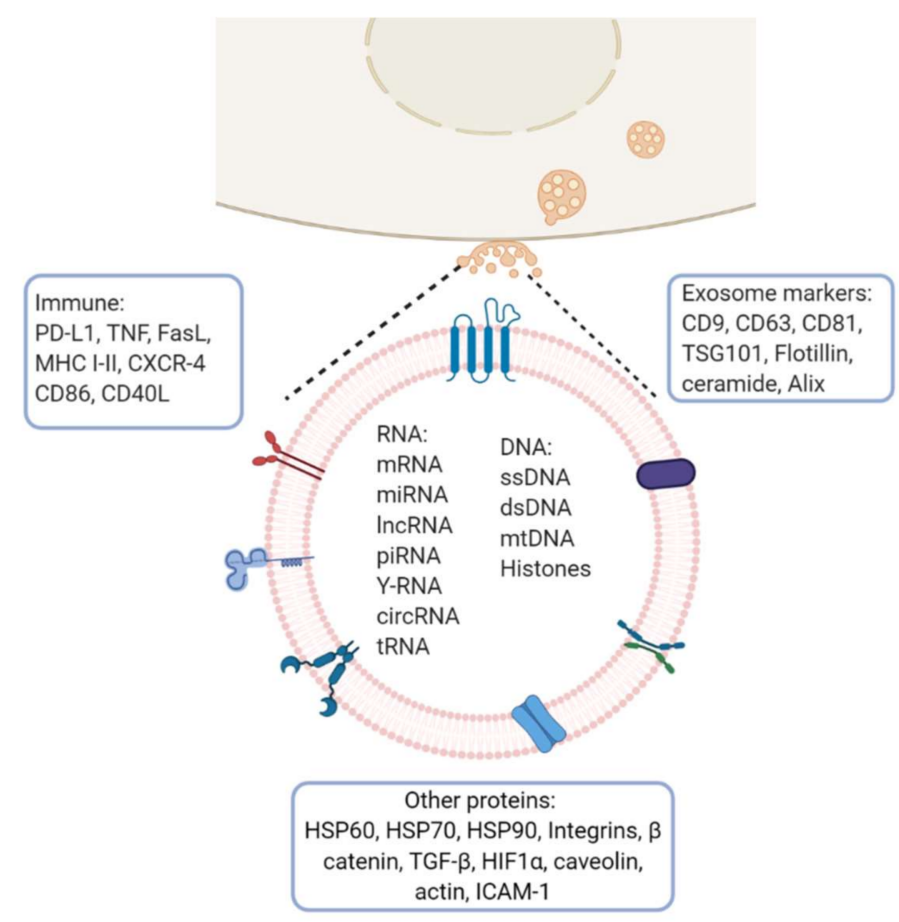

Figure 2. Exosome molecular cargo: Depending on their cellular origin (immune, cancer, epithelial or mesenchymal cells), exosome may have diverse molecular cargos which may include immunomodulatory proteins involved in vesicle trafficking and enzymes with functional activities in target cells. In the lumen of exosomes, they transport nucleic acids such as DNA, mRNA, miRNA, IncRNA and other RNA species. Image created with biorender.com.

In general, exosome protein expression is related to the cell from which they originate, but also depends on their physiological status, e.g., exosomes released from both human and murine B-cells transformed by the Epstein-Barr virus secrete antigen-presenting vesicles capable of inducing antigen-specific MHC class II-restricted T-cell responses, suggesting a role for exosomes in antigen presentation in vivo [21]. They play a role in hepatitis B virus transmission and NK-cell dysfunction during chronic infection [22], can favor cancer progression, metastasis and drug resistance by altering gene expression in surrounding and distant cells [23], and be a source of proteins that could have clinical application as biomarkers for the early detection, diagnosis, prognosis and treatment of diseases [24].

\section{Role of Exosomes in Antigen Presentation}

Immune system modulation by exosomes can occur between cells of the same or different lineages. Effector cells (T, NK, APC, and mast cells) may give or receive information through receptor-ligand interactions or by extracellular vesicles. Tumor cell-derived exosomes (TEX) can prevent immune activation, DC maturation, T and NK cell-mediated cytotoxicity, or promote immune suppression, tolerance, and T-cell apoptosis because they can carry a large diversity of molecules to mediate intercellular communication, (Figure 1) [25,26].

As the first signal required for the activation of an effective immune response is the recognition of the HLA/peptide complexes by the T-cell receptor, and exosomes released by mature APCs express HLA/peptide complexes and costimulatory molecules necessary for T-cell activation, it seems that mature APC exosomes constitute a presentation route as crucial as that of professional APCs for T-cell activation $[27,28]$. In murine models, bone marrow DCs (BMDCs) have been shown to secrete exosomes capable of amplifying immune responses in vivo by transporting antigens to induce antigen-specific CD4 and CD8 T-cell activation [29-31]. On the other hand, regulatory activities are also carried out by exosomes. A tolerance mechanism mediated by IL-10 production, with an effect on 
regulatory T-cells (Treg) related to the accumulation of MFG-E8/lactadherin, has been described on exosomes from immature DCs [32,33].

Clayton et al. reported that human tumor-derived exosomes express ligands for NKG2D and TGF $\beta 1$ that triggered downregulation of NKG2D surface expression by NK and CD8(+) T-cells as an evasion mechanism to avoid their recognition and immune destruction, suggesting that NKG2D is a physiological target for exosome-mediated immune evasion in cancer [34]. The downregulation of pro-inflammatory cytokines such as IL-12p40, IL-23p19, TNF- $\alpha$, and IL-1 $\beta$, has also been described induced by endothelial cell-derived exosomes and the overexpression of immunosuppressive ones such as IL-10, MRC1 and TGF- $\beta$, to prevent damage and promote tissue regeneration favoring tumor growth and metastasis $[35,36]$. On the other hand, DCs pulsed with tumor peptides release exosomes with the ability to stimulate CD8+ T-cell proliferation and differentiation into cytotoxic T-cells. It has been also reported that exosomes can stimulate cytotoxic effects on NK cells by membrane IL-15R $\alpha$ and NKG2D expression, which induce proliferation and membrane IFN production $[37,38]$ Exosomes derived from DCs, which express major histocompatibility complex (MHC) and costimulatory molecules, have been used for antitumor vaccines because, besides to be a source of tumor peptides, they also express molecules essential for the induction of immune responses, such as MHC I, MHC II and costimulatory CD40, CD54, and CD80 [39].

NKG2D is an activating receptor for CD8+ and T-cells, NK and NKT cells. Its expression can be deregulated by its soluble ligands and by growth factors such as TGF $\beta 1$, secreted by the tumor as an evasion mechanism to prevent its recognition and immune destruction. In fact, TGF $\beta 1$ and soluble ligands for NKG2D have been detected in cancer cell lines and in tumor cells isolated from mesothelioma pleural effusions. Downregulation of NKG2D expression on NK and on the CD8+ T-cell surface [34], or the decrease in the secretion of the proinflammatory cytokines induced by these exosomes, prevents damage and promotes tissue regeneration, thus promoting tumor growth and metastasis $[35,36]$.

Tumor-derived exosomes and micro vesicles (EMVs) are key mediators shed by cancer cells with the ability to sensitize neighboring cells in the tumor microenvironment, thus promoting cancer invasion and metastasis. EMVs derived from hypoxic tumor cells differ qualitatively from those derived from normoxic tumor cells. Hypoxic EMVs inhibit NK cell function to a greater extent than normoxic ones, by transferring TGF- $\beta 1$ to NK cells, inhibiting NK cell function and decreasing NKG2D expression on the NK cell surface. They also carry high levels of miR-210 and miR-23a, which act as additional immunosuppressive factors by targeting CD107a expression in NK cells. By releasing extracellular vesicles into the hypoxic tumor microenvironment, tumor cells can educate NK cells to decrease their antitumor immune response [40].

\section{Tumor-Derived Exosome-Mediated Immune Suppression}

Exosome production by tumor cells has been implicated in cancer-associated immune suppression, and it has been proven that the body fluids of cancer patients contain large numbers of tumor exosomes (TEX) capable of downregulating the functions of immune cells and promoting tumor progression through various mechanisms including the transport of molecules such as proteins and nucleic acids. There is evidence that miRNAs, secreted by the tumor into exosomes can regulate gene expression in target cells through canonical binding to their target mRNAs. Furthermore, it has been shown that miR-21 and miR-29a secreted by the tumor can function by binding to the Toll-like receptors (TLR) family on immune cells. This binding triggers a prometastatic inflammatory response through the activation of NF- $\kappa \beta$, which favors tumor development and metastasis [41]. Unlike exosomes released by normal cells, TEX are involved in the regulation of peripheral tolerance. They have the ability to down-regulate CD3 $\zeta$ and JAK3 expressions in primary activated T-cells, induce Fas/FasL-mediated apoptosis in TCD8+ lymphocytes, and promote CD4+CD25- T-cell proliferation and their further conversion 
to CD4+CD25hi+FOXP3+ Treg cells expressing IL-10, TGFß1, CTLA-4, GrB/perforin to mediate immunosuppression [42,43].

TEX, in addition to regulating the immune effector cell (TL, NK, APC) function, are also involved in blocking myeloid cell maturation to DCs through the expression of TGF $\beta$, which induces a CD14+HLA-DR-phenotype, characteristic of myeloid derived suppressor cells (MDSC). These MDSC include DC precursors with a suppressive effect on proliferation and cytotoxic functions of tumor-specific T-cells by altering antigen processing and presentation, producing inhibitory factors such as nitric oxide and reactive oxygen species [44], and have been described in the peripheral blood of patients with oncological pathologies including hepatocellular carcinoma, bladder carcinoma, glioblastoma and multiple myeloma [45] (Figure 3). A murine model of breast cancer showed that tumor exosome induction of IL-6 expression can block bone marrow DC differentiation, and that pancreatic cancer-derived exosomes can regulate the expression of TLR4 and cytokines, such as TNF $\alpha$ and IL-12 expression in DCs through miR-203 [46,47].

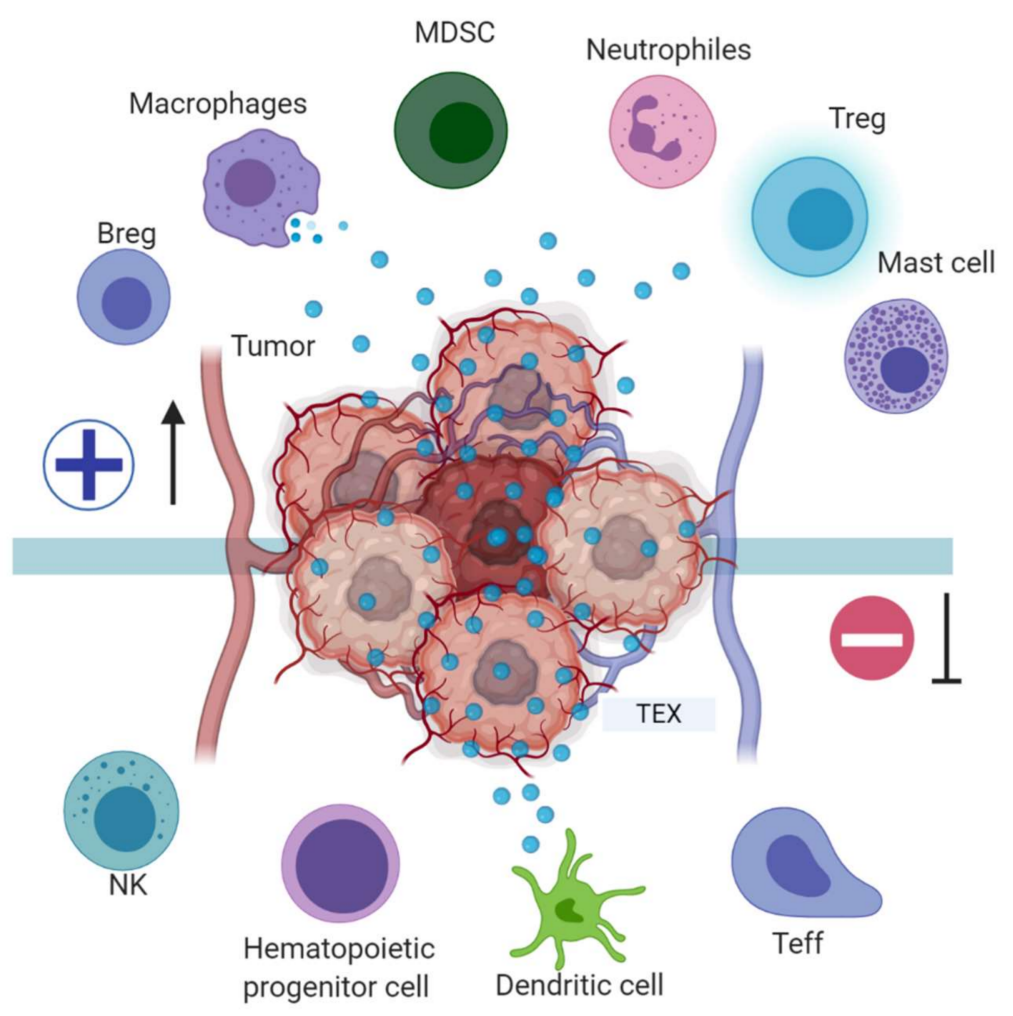

Figure 3. Tumor immune escape mediated by tumor exosomes (TEX). TEX favor immune escape by bearing proteins such as TGF- $\beta$, FasL, TRAIL, PD-L1, and HSP90, and miRNA such as miR23a, miR-24-3p and miR-214, to dysregulate NK, T and B effector cells function. In dendritic cells, exosome miR-203 may downregulate TLR4 expression and increase IL-6 production, inhibiting the differentiation of myeloid precursors into DCs. TEX bearing miR-21, miR-29a, and proteins such as CSF-1, CCL2, and TGF $\beta$ may drive macrophage polarization to a M2-like phenotype and promote MDSCs differentiation contributing to cancer progression. Image created with biorender.com.

\section{Exosome-Mediated Crosstalk between Tumor and Immune Infiltrating Cells}

Cancer-associated immune suppression contributes to cancer progression and is related to poor prognosis. There is evidence of the wide variety of molecular and cellular mechanisms used by the tumor to evade the host antitumor immune response, and the impact these mechanisms have on the maintenance of immune homeostasis and the response to immunotherapies aimed at activating the antitumor immune response.

It was reported that microvesicles and exosomes released by tumor cells contribute to cancer immunosuppression by inducing, in T-cells, the transition from the effector pheno- 
type (CD4+CD25-) to the regulator (CD4+CD25+Foxp3+) phenotype, its clonal expansion, and activation. Interactions of tumor extracellular vesicles and exosomes with Treg cells represent a mechanism involved in the regulation of peripheral tolerance, since tumor infiltrating and peripheral blood circulating Treg cells are capable of inducing systematic effector T-cell apoptosis favoring the tumor escape from immune surveillance and are associated with a poorer prognosis. Thus, depletion of Treg cells before immunotherapy could increase the success of effector T-cell based immunotherapies [48].

TEX regulate Treg suppressor function and increase resistance to apoptosis by inducing expression of FasL, IL-10, TGF- $\beta 1$, CTLA-4, granzyme B and perforin $[49,50]$. In cancer cell lines (bladder, colorectal, prostate and breast) exosomes expressing CD39 and CD73 ectonucleotidases have been described that can indirectly modulate the effector immune cells activity in the tumor environment as a mechanism of Treg cell-mediated immune regulation, [51]. In this case, the extracellular adenosine generated by exosomes expressing CD39 and CD73 interferes with antitumor immune responses, and thus, CD39 and CD73 inhibition effects have been studied for their possible clinical application against cancer $[52,53]$. It has also been reported that tumor cells produce miRNAs that are loaded into exosomes and secreted to favor the evasion of the immune response. One of these miRNAs, miRNA214 , is overexpressed in several types of human cancer and in murine models, promoting the expansion of Treg cells that produce high levels of IL-10 [54]. It was reported that tumor cells resistant to gefitinib could transfer this resistance to sensitive tumor cells in non-small cell lung cancer, thus suggesting that this effect is due to the miR-214 transfer in exosomes [55].

B-cells are important players in the tumor-induced immune response, and they constitute the second most abundant population of tumor-infiltrating lymphocytes. However, there is a population of regulatory B-cells (B-reg) that favor tumor development through IL-10, IL-35, TGF- $\beta$ and IL-21 production, which prevent the expansion of proinflammatory cells [56]. There is evidence that Breg cells interfere with the antitumor response by mechanisms such as lymphotoxin production, which promotes tumor growth by inducing angiogenesis [57]. B-cells contain a specialized late endosomal compartment that hosts newly synthesized HLA-II molecules. Exosomes secreted by B-cells are capable of presenting antigens and inducing CD4 T-cell antigen-specific responses [58].

Tumor-derived extracellular vesicles can affect the function of B-cells in different ways, inducing antibodies production which, although capable of activating immune responses, do not have the antigenic potential of tumor-derived HLA-I binding peptides to activate the CD8+ T-cells. However, when these low antigenic antibodies bind the Fc $\gamma$ receptors on myeloid cells, they induce their differentiation towards MDSC capable of suppressing the CD4+ and CD8+ T-cells antitumor immune responses [21], inducing differentiation of naive $B$ cells into TGF- $\beta$-producing regulatory $B$ cells with immune suppressor functions on CD8+ T-cells proliferation [59], or inducing IL-10 production, which also promotes the generation of regulatory B-cells capable of inhibiting T-cell activity [60].

Although the restoration of normal lymphocyte homeostasis is probably the most important component of an adequate response to immunotherapy, the role of other types of immune cells infiltrating the tumor cannot be ignored. Macrophages constitute one of the most abundant cell populations in the innate antitumor immune response. In the tumor microenvironment, there is cross-communication between the tumor, immune cells that infiltrate the tumor and normal tissue cells. It has been shown that invasion induced by tumor-associated macrophages (TAM) requires the positive regulation of Wnt5a to activate Wnt signaling, independent of $\beta$-Catenin in breast cancer cells, increasing their invasive capacity. In MCF-7 cell supernatants, it has been observed that microvesicles and exosomes occur with the ability to induce overexpression of Wnt5a in TAMs and transfer it to tumor cells, to improve their invasiveness [61]. In addition, proteomics studies have shown that in ovarian cancer, exosomes derived from TAMs can inhibit endothelial cell migration by interfering with the miR-146b-5p/TRAF6/NF-kB/MMP2 pathway. However, tumor cell-derived exosomes can transfer long noncoding RNAs (lncRNA) to reverse the TAMs' 
effect on endothelial cells [62]. In gastric cancer, TAM-derived exosomes miR-21 transfer confers resistance to cisplatin [63].

Some normal cells can also participate in cancer development and progression by exosome mediated mechanisms. Fibroblasts, due to their plasticity and adaptability, are able to survive in severe stress environments and may contribute to cancer development. Cross talk between cancer-associated fibroblasts (CAF) and tumor cells favor endothe-lial cells and pericytes recruitment to the tumor and stimulates the development of an appropriate tumor microenvironment (TME) (Figure 4). They can introduce metabolic and immune changes in the tumor niche to favor angiogenesis, extracellular matrix remodeling, metastasis, and escape from the immune recognition and destruction through the secretion of exosomes and proteins such as growth factors, chemokines and extracellular matrix [64-66].

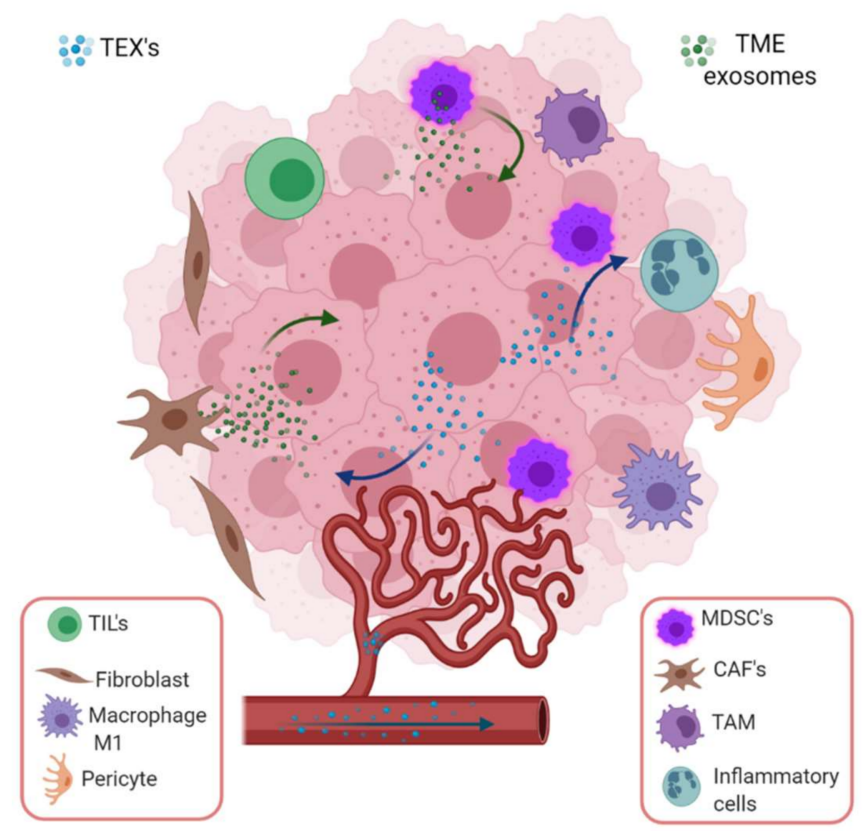

Figure 4. Tumor-derived exosome mediated intercommunication among stroma and tumor cells in a specific microenvironment. TEX induce epithelium mesenchymal transition (EMT), invasiveness, migration, proliferation and stemness in stroma (endothelial cells, fibroblasts, pericytes) and immune cells. In the tumor microenvironment, the most important cargoes of exosomes are HIF-1 $\alpha$, matrix metalloproteinase such as MMP-13, MMP-14, and ncRNAs such as miR-21, miR-135b and lncRNAUCA1, which stimulate EMT. On the other hand, stromal cell-derived exosomes also boost cancer cells employing ncRNA (miR-21, miR-221, miR-222, miR-223, miR-100) or proteins (apolipoprotein E, Wnt, NOTCH3, TGF $\beta$ R, KRAS, TNF $\alpha$ ). Image created with biorender.com.

New biomarkers associated with the promotion of growth, migration, metastasis and resistance to drugs with potential clinical application in CAF-derived exosomes, were identified [67]. It was also demonstrated that CAF secreted exosomes can affect the tumor phenotype and, in turn, exosomes released by tumor cells can activate CAF [68], as it occurs in ovarian cancer, where exosomes released by tumor cells prepare the microenvironment at a distance to favor metastatic invasion by regulating intercellular communication between tumor cells and normal stromal cells, CAF and immune cells that infiltrate the tumor [69]. Hepatocellular carcinoma (HCC) cells with high metastatic potential exhibit a more remarkable ability to convert normal fibroblasts to CAF than HCC cells with low metastatic potential, suggesting that communication between tumor cells and fibroblasts is mediated by tumor-derived exosomes that control pulmonary metastasis in HCC, and thus could be considered as potential targets for the prevention and treatment of cancer metastases [54]. 


\section{Exosomes and Epithelial-Mesenchymal Transition (EMT)}

Invasion and metastasis are acquired capacities of tumors characterized by the acquisition of mesenchymal cell phenotypes by epithelial tumor cells. These cells, with motile capacity, trigger the formation of metastasis in organs distant from the primary tumor [70]. The epithelial-mesenchymal transition is a reversible cellular program that occurs in normal physiological processes such as embryonic development and wound healing. During this process, cell-cell and extracellular matrix-cell interactions are remodeled with the detachment of epithelial cells from the basement membrane and the activation of transcriptomic profiles stimulated by stromal components of the tumor tissue [71]. Exosomes from the serum of patients with cancer exhibit high miRNAs expression associated with migration and invasiveness of cancer cells. miR-222 is overexpressed in lymphatic metastasis of breast cancer patients conferring a more aggressive phenotype both in vitro and in vivo. In estrogen receptor-positive breast tumors, miR-222 has been associated with high histological grade, high Ki67 proliferation rates and HER2 amplification, as well as resistance to hormonal treatment through EMT activation [72]. The primary anatomical location of metastases with the worst prognosis in gastric cancer is peritoneal metastasis whose molecular characterization and understanding is not clear. Shen et al. reported the differential expression of miR-196, miR-92 and miR1307 in ascites-derived exosomes of gastric cancer patients, with the activation of cancer-associated fibroblasts in the peritoneum [73]. Serum exosomes from patients with glioblastoma exhibit high miR-148a expression associated with migration and proliferation in an in vitro model in which gene suppression reduced proliferation and metastasis in glioblastoma cells (Table 1).

Tumor derived exosomes are one of the main strategies used by tumors to promote cancer development and metastatic spread. Via exosomal transport, they may induce new blood vessel formation by transporting vascular endothelial growth factor (VEGF), fibroblast growth factor (FGF), platelet-derived growth factor (PDGF), essential fibroblast growth factor (bFGF), tumor necrosis factor-alpha (TNF $\alpha$ ) and interleukin-8 (IL-8), among others, to favor angiogenesis and metastasis, as well as EMT [74]. Long noncoding RNAs (lncRNA) participate in angiogenesis development of various types of cancer. lncRNA-H19 can be transported in exosomes and received by endothelial cells which promote cell adhesion and angiogenesis in a liver cancer model [75]. The long intergenic noncoding RNA-POU3F3 (Linc-POU3F3) is overexpressed in hepatocellular carcinoma [76], colorectal cancer and glioma [77], promoting tumor cell survival, proliferation, migration and invasion mediated by TEX-educated cells. The LncRNA MALAT1, associated with lung cancer metastasis, was described in ovarian adenocarcinoma as a promoter of angiogenesis and progression, [78]

Table 1. Biomolecules contained in exosomes and their effect on angiogenesis and metastasis.

\begin{tabular}{|c|c|c|c|c|}
\hline Affected Process & Source of Exosomes & Molecular Cargo & Role in Cancer Development & Ref. \\
\hline \multirow[t]{2}{*}{ Angiogenesis } & \multirow[t]{2}{*}{ Gastric cancer patients (GC) } & \multirow[t]{2}{*}{ miR-155 } & $\begin{array}{l}\text { Exosome miR-155 inhibit FOXO3a } \\
\text { expression promoting angiogenesis and } \\
\text { progression in GC. Potential biomarker } \\
\text { for migration, angiogenesis, and poor } \\
\text { prognosis.Novel target for } \\
\text { anti-angiogenesis therapy }\end{array}$ & [79] \\
\hline & & & $\begin{array}{c}\text { Exosome miR-155 downregulate c-MYB } \\
\text { and upregulate VEGF expression } \\
\text { promoting growth, angiogenesis and } \\
\text { metastasis in GC. }\end{array}$ & [80] \\
\hline
\end{tabular}


Table 1. Cont.

\begin{tabular}{|c|c|c|c|c|}
\hline Affected Process & Source of Exosomes & Molecular Cargo & Role in Cancer Development & Ref. \\
\hline & \multirow{2}{*}{$\begin{array}{l}\text { Nasopharyngeal cancer } \\
\text { (NPC) }\end{array}$} & miR-17-5p & $\begin{array}{l}\text { Exosome miR-17-5p promotes } \\
\text { angiogenesis in NPC though inhibition of } \\
\text { BAMBI expression and regulation of } \\
\text { AKT/VEGF-A signaling. }\end{array}$ & [81] \\
\hline & & Mir-23a & $\begin{array}{l}\text { Overexpression of Exosome miR-23a in } \\
\text { NPC promote angiogenesis in vitro and } \\
\text { in vivo by targeting the testis-specific } \\
\text { gene antigen (TSGA10), an angiogenesis } \\
\text { inhibitor. }\end{array}$ & [82] \\
\hline & Melanoma & miR-155 & $\begin{array}{l}\text { Overexpression of Exosome miR-155 in } \\
\text { melanoma reprogram fibroblasts into } \\
\text { CAFs by targeting SOCS1, which activates } \\
\text { JAK2/STAT3 signaling pathway and } \\
\text { increase the expression levels of VEGFa, } \\
\text { FGF2, and MMP9 in fibroblasts promoting } \\
\text { angiogenesis.Potential therapeutic target } \\
\text { to inhibit melanoma angiogenesis. }\end{array}$ & [83] \\
\hline & Ovarian carcinoma $(\mathrm{OC})$ & miR-205 & $\begin{array}{l}\text { Exosome miR-205 from OC cells promote } \\
\text { metastasis by inducing angiogenesis } \\
\text { in vitro and in vivo via the PTEN-AKT } \\
\text { pathway. Potential therapeutic target for } \\
\text { OC. }\end{array}$ & [84] \\
\hline & $\begin{array}{l}\text { Non-small cell lung } \\
\text { carcinoma (NSCLC) }\end{array}$ & miR-619-5p & $\begin{array}{l}\text { Exosome miR-619-5p promotes NSCLCs } \\
\text { growth and metastasis by regulating } \\
\text { RCAN1.4, a tumor suppressor protein. }\end{array}$ & [85] \\
\hline & Chondrosarcoma & lncRNA RAMP2-AS1 & $\begin{array}{l}\text { Exosome lncRNA RAMP2-AS1 from } \\
\text { chondrosarcoma cells promotes } \\
\text { angiogenesis proliferation, migration and } \\
\text { tube formation favoring by the } \\
\text { RAMP2-AS1/miR-2355-5p/VEGFR2 axis } \\
\text { in human umbilical vein endothelial cells } \\
\text { (HUVEC). }\end{array}$ & [86] \\
\hline \multirow{2}{*}{ Metastasis } & Gastric cancer (GC) & $\operatorname{miR}-27 a$ & $\begin{array}{l}\text { Exosome miR-27a from GC cells induce } \\
\text { fibroblasts reprogramming into CAFs, } \\
\text { promoting proliferation, motility, and } \\
\text { metastasis in vitro and in vivo, and } \\
\text { over-expression of miR-27a on CAFs } \\
\text { derived exosomes could increase the } \\
\text { malignant behavior of GC cells. miR-27a } \\
\text { also downregulate CSRP2, increasing GC } \\
\text { cells proliferation and motility. }\end{array}$ & [87] \\
\hline & $\begin{array}{l}\text { Oral squamous cell } \\
\text { carcinoma (OSCC) }\end{array}$ & miR-34a-5p & $\begin{array}{l}\text { Exosome miR-34a-5p from OSCC binds to } \\
\text { AXL to inhibit the tumorigenesis } \\
\text { suppressing tumor cell proliferation and } \\
\text { metastasis. However, miR-34a-5p in } \\
\text { CAF-derived exosomes was significantly } \\
\text { reduced and by this mean, } \\
\text { miR-34a-5p/AXL axis may increase } \\
\text { aggressiveness in oral cancer cells by } \\
\text { inducing EMT to promote metastasis by } \\
\text { the AKT/GSK-3 / } \beta \text {-catenin/snail } \\
\text { signaling which activate MMP-2 and } \\
\text { MMP-9 expression. }\end{array}$ & [88] \\
\hline
\end{tabular}


Table 1. Cont.

\begin{tabular}{|c|c|c|c|c|}
\hline Affected Process & Source of Exosomes & Molecular Cargo & Role in Cancer Development & Ref. \\
\hline & Breast cancer $(\mathrm{BC})$ & $\operatorname{miR}-181 d-5 p$ & $\begin{array}{l}\text { CAF-derived exosomes can transfer } \\
\text { miR-181d-5p to enhance the } \\
\text { aggressiveness of breast cancer by } \\
\text { promoting tumor growth via } \\
\text { downregulation of CDX2 and HOXA5 to } \\
\text { favor cell proliferation, invasion, } \\
\text { migration and EMT. }\end{array}$ & [89] \\
\hline
\end{tabular}

carcinoma cells promote migration and invasion of recipient cells by decreasing

E-cadherin expression, increasing vimentin expression and promoting EMT via TGF- $\beta /$ Smad signaling.

Hepatocellular carcinoma (HCC).

MALAT1
lncRNA RPPH1
Colorectal cancer(CRC)
miR-499a-5p
Anti-angiogenesis therapies appear to be useful for the treatment of HCC, although metastasis may develop over time.

Increased expression of YAP1 around tumor-associated blood vessels indicates a role in angiogenesis for this protein. Its inhibition in endothelial cells reduces proliferation and tube formation.

However, inhibition of YAP1 leads to an increase in the release of exosomes containing MALAT1 into the tumor microenvironment. Exosome transfer of MALAT1 to hepatic cells increase invasion and migration via the activation of ERK1/2 signaling.

lncRNA RPPH1 is upregulated in CRC tissues associated with advanced TNM stages and poor prognosis. RPPH1 promote CRC metastasis in vitro and in vivo by inducing EMT of CRC cells via interacting with $\beta$-III tubulin (TUBB3)

CRC cell-derived exosomes transport RPPH1 into macrophages mediating M2 polarization, which promotes metastasis and proliferation in CRC cells.

MiR-499a-5p was upregulated in highly metastatic lung cancer cell line and in their exosomes promoting cell proliferation, migration and EMT via mTOR pathway.MiR-499a-5p knockdown suppress these processes in vitro supporting the potential diagnostic and therapeutic value of cancer-derived exosome miR-499a-5p. 
Table 1. Cont.

\begin{tabular}{|c|c|c|c|c|}
\hline Affected Process & Source of Exosomes & Molecular Cargo & Role in Cancer Development & Ref. \\
\hline & Glioma & miR-1246 & $\begin{array}{l}\text { Hypoxic glioma-derived exosomes } \\
\text { (H-GDE) induce M2 macrophage } \\
\text { polarization, which promotes glioma } \\
\text { proliferation, migration and invasion } \\
\text { in vitro and in vivo.MiR-1246 is the most } \\
\text { abundant in H-GDE, and in the CSF of } \\
\text { GBM patients, but its expression } \\
\text { decreases after tumor resection. M2 } \\
\text { macrophage polarization in H-GDE is } \\
\text { mediated by miR-1246 targeting of } \\
\text { TERF2IP to activate STAT3 and inhibit the } \\
\text { NF- } \mathrm{KB} \text { signaling pathways. }\end{array}$ & [94] \\
\hline & $\begin{array}{l}\text { Clear cell renal cell } \\
\text { carcinoma (ccRCC) }\end{array}$ & ApoC1 & $\begin{array}{l}\text { ApoC1 overexpression in ccRCC cells is } \\
\text { related to invasion, poor survival and } \\
\text { EMT induction, thus promoting } \\
\text { metastasis. In contrast, ApoC1 } \\
\text { downregulation inhibits these effects. } \\
\text { Transfer of exosome ApoC1 from ccRCC } \\
\text { to endothelial cells promotes metastasis } \\
\text { by activation of STAT3. This metastatic } \\
\text { potential is suppressed by inhibition of } \\
\text { DPP- } 4 \text {. }\end{array}$ & [95] \\
\hline
\end{tabular}

Legend: FOXO3a, The Forkhead box O-3a; GC, Gastric cancer; c-MYB, MYB proto-oncogene transcription factor; VEGF, Vascular Endothelial Growth Factor; BAMBI, BMP and Activin Membrane Bound Inhibitor; PTEN, Phosphatase and tensin homolog; AKT, serinethreonine protein kinase; TSGA10, Testis-Specific 10; CAFs, Cancer-associated fibroblasts; FGF2, Fibroblast Growth Factor 2; MMP9, Matrix Metallopeptidase 9; OC, Ovarian cancer; RCAN1.4, Regulator of Calcineurin 1 Isoform 4; RAMP2-AS1, RAMP2 Antisense RNA 1; HUVECs, Human umbilical vein endothelial cells; CSRP2,Cysteine And Glycine Rich Protein 2; OSCC, Oral squamous cell carcinoma; AXL, AXL Receptor Tyrosine Kinase; GSK-3 $\beta$, Glycogen Synthase Kinase 3 Beta; CDX2, Caudal Type Homeobox 2; HOXA5, Homeobox A5; EMT, Epithelial-Mesenchymal Transition; TGF- $\beta$, Transforming Growth Factor Beta; MALAT1, Metastasis Associated Lung Adenocarcinoma Transcript 1; ERK1/2, The extracellular signal-regulated kinase 1/2; YAP1, Yes 1 Associated Transcriptional Regulator; RPPH1, Ribonuclease P RNA Component H1; TNM, Tumor, Node, Metastases; GBM, Glioblastoma; TERF2IP, TERF2 Interacting Protein; ApoC1, Apolipoprotein C1; STAT3, Signal Transducer And Activator of Transcription 3.

\section{Current Methods and Applications for Exosome-Based Cancer Therapies}

The potential application of exosomes in the clinic is still emerging, and studies on their utility in the diagnosis and the treatment of many pathologies have increased during the past years. TEX represents a rich source of tumor antigens, genetic material, and immune stimulatory molecules [96]. Exosome clinical applications are not limited to their use as a source of biomarkers for diagnosis, prognosis or follow-up. Their unique capacity to transport functional cargos such as proteins and nucleic acids could be exploited using them as therapeutic vehicles to target cancer therapies to specific places with difficult access, such as the brain $[97,98]$. Additionally, as exosomes have the ability to stimulate specific antitumor immune responses, they also have potential application in developing cancer vaccines [99].

Exosomes are being actively explored as therapeutic agents because, in contrast to liposomes, they can deliver the molecular cargo without immune clearance [100] and have shown to be well tolerated [101,102]. Doxorubicin and other chemotherapeutic compounds such as paclitaxel loaded into exosomes for cancer therapy demonstrated antitumor efficacy and low toxicity when tested in mice $[103,104]$. miRNA or siRNA, administered in exosomes are protected from the ribonucleases action and could exert their function at distant sites in murine cancer models [105,106] Table 2. 
Table 2. Pre-clinical and clinical trials using exosomes for cancer therapy.

\begin{tabular}{|c|c|c|c|}
\hline Clinical Approach & Source of Exosomes & $\begin{array}{c}\text { Clinical and Pre-Clinical } \\
\text { Trial Features }\end{array}$ & Reference or Clinical Trials \\
\hline \multirow{3}{*}{$\begin{array}{l}\text { Extracellular vesicles-based } \\
\text { cancer vaccine }\end{array}$} & Dendritic cell & $\begin{array}{l}\text { Combined Immunotherapy } \\
\text { using metronomic } \\
\text { cyclophosphamide followed } \\
\text { by vaccination with tumor } \\
\text { antigen-loaded dendritic } \\
\text { cell-derived exosomes to } \\
\text { inhibit Treg cell functions and } \\
\text { restore T and NK cell effector } \\
\text { functions while activating } \\
\text { innate and adaptive } \\
\text { immunity. }\end{array}$ & $\begin{array}{c}{[107-111]} \\
\text { NCT01159288 }\end{array}$ \\
\hline & $\mathrm{T}$ cell & $\begin{array}{l}\text { A novel HER2 specific } \\
\text { exosome/T-cell vaccine using } \\
\text { polyclonal CD4+ T cells up } \\
\text { taking exosomes released by } \\
\text { HER2-specific dendritic cells } \\
\text { may provide a new } \\
\text { therapeutic alternative for } \\
\text { patients with } \\
\text { trastuzumab-resistant HER2+ } \\
\text { breast cancer. }\end{array}$ & {$[112,113]$} \\
\hline & Tumor cells & $\begin{array}{l}\text { Prostate cancer cell-derived } \\
\text { exosomes were used to } \\
\text { prepare a vaccine anchoring } \\
\text { an IFN- } \gamma \text { fusion protein on the } \\
\text { surface of prostate cancer } \\
\text { cell-derived exosomes, which } \\
\text { retained its bioactivity and } \\
\text { significantly inhibited tumor } \\
\text { growth and prolonged the } \\
\text { survival time of mice with } \\
\text { prostate cancer. }\end{array}$ & [114] \\
\hline $\begin{array}{l}\text { Tumor-associated or cell lines } \\
\text { exosomes }\end{array}$ & Tumor cells & $\begin{array}{l}\text { Exosomes secreted by diffuse } \\
\text { large B cell lymphoma } \\
\text { (DLBCL) induce apoptosis } \\
\text { and upregulation of PD-1 in T } \\
\text { cells. However, dendritic cells } \\
\text { after being pulsed with } \\
\text { DLBCL exosomes can } \\
\text { stimulate T cells, increase IL-6 } \\
\text { and TNF } \alpha \text { expression and } \\
\text { decrease the production IL-4 } \\
\text { and IL-10. In another study, } \\
\text { exosomes derived from } \\
\text { heat-shocked mouse B } \\
\text { lymphoma cells contained } \\
\text { more HSP60 and HSP90, } \\
\text { MHC I, MHC II, CD40, CD86, } \\
\text { RANTES and IL-1ß, which } \\
\text { induce phenotypic and } \\
\text { functional maturation of } \\
\text { dendritic cells and activate } \\
\text { CD8+ T cells to produce an } \\
\text { antitumor effect }\end{array}$ & {$[115,116]$} \\
\hline
\end{tabular}


Table 2. Cont.

\begin{tabular}{|c|c|c|c|}
\hline Clinical Approach & Source of Exosomes & $\begin{array}{c}\text { Clinical and Pre-Clinical } \\
\text { Trial Features }\end{array}$ & Reference or Clinical Trials \\
\hline & $\begin{array}{l}\text { Natural killer cell-derived } \\
\text { exosomes }\end{array}$ & $\begin{array}{l}\text { NK cell markers such as } \\
\text { NKG2D, CD94, perforin, } \\
\text { granzymes and CD40L are } \\
\text { expressed in NK-derived } \\
\text { exosomes, along with other } \\
\text { molecules involved in } \\
\text { cytotoxicity, homing, cell } \\
\text { adhesion and immune } \\
\text { activation, suggesting that NK } \\
\text { exosomes might be potentially } \\
\text { exploited in support of cancer } \\
\text { therapy. }\end{array}$ & {$[117,118]$} \\
\hline & $\begin{array}{c}\text { CAR-T cell/CTL-derived } \\
\text { exosomes }\end{array}$ & $\begin{array}{l}\text { CAR-T cells release exosomes } \\
\text { that carry CAR and express a } \\
\text { high level of cytotoxic } \\
\text { molecules capable of } \\
\text { inhibiting tumor growth. } \\
\text { They do not express PD1 and } \\
\text { have cytotoxic activity in vitro. } \\
\text { The presence of CTL surface } \\
\text { membrane molecules in } \\
\text { CTL-derived exosomes } \\
\text { ensures the unidirectional } \\
\text { delivery of the lethal hit to } \\
\text { targeted tumor cells. }\end{array}$ & {$[119,120]$} \\
\hline & $\begin{array}{l}\text { Mesenchymal stromal } \\
\text { cells-derived exosomes }\end{array}$ & $\begin{array}{l}\text { To determine the best dose } \\
\text { and side effects of exosomes } \\
\text { derived from mesenchymal } \\
\text { stromal cells loaded with } \\
\text { KrasG12D siRNA for the } \\
\text { pancreatic cancer treatment. }\end{array}$ & NCT03608631 \\
\hline Genetically Engineered & Antibodies on exosomes & $\begin{array}{l}\text { Synthetic multivalent } \\
\text { antibodies retargeted } \\
\text { exosomes (SMART-Exo) were } \\
\text { genetically modified for } \\
\text { displaying two distinct types } \\
\text { of monoclonal antibodies on } \\
\text { the exosome surface. They can } \\
\text { simultaneously target } \\
\text { tumor-associated human } \\
\text { EGFR and T-cell surface CD3 } \\
\text { receptor redirecting and } \\
\text { activating T cells which } \\
\text { exhibit a highly potent and } \\
\text { specific antitumor activity } \\
\text { against EGFR-expressing } \\
\text { cancer cells. }\end{array}$ & {$[121,122]$} \\
\hline
\end{tabular}


Table 2. Cont.

\begin{tabular}{|c|c|c|c|}
\hline Clinical Approach & Source of Exosomes & $\begin{array}{c}\text { Clinical and Pre-Clinical } \\
\text { Trial Features }\end{array}$ & Reference or Clinical Trials \\
\hline Natural product & $\begin{array}{c}\text { Therapeutic effect of plant } \\
\text { exosomes }\end{array}$ & $\begin{array}{l}\text { To determine the effect of } \\
\text { exosome-delivered curcumin } \\
\text { on immune modulation, } \\
\text { cellular metabolism and } \\
\text { phospholipid profile in } \\
\text { normal colon tissue and colon } \\
\text { tumors of newly diagnosed } \\
\text { colon cancer patients who are } \\
\text { undergoing surgery. To } \\
\text { investigate the ability of plant } \\
\text { (grape) exosomes to prevent } \\
\text { oral mucositis associated with } \\
\text { chemo-radiation treatment of } \\
\text { head and neck cancer. } \\
\text { Fruit-derived exosomes and } \\
\text { curcumin should not generate } \\
\text { any side-effects. }\end{array}$ & $\begin{array}{l}\quad[123] \\
\text { NCT01294072, } \\
\text { NCT01668849 }\end{array}$ \\
\hline \multirow{3}{*}{ Chemical drugs } & \multirow{3}{*}{$\begin{array}{c}\text { Exosome-based drug delivery } \\
\text { platform for } \\
\text { chemotherapeutic agents }\end{array}$} & $\begin{array}{l}\text { Exosomes released by } \\
\text { autologous macrophages } \\
\text { loaded with paclitaxel (PTX) } \\
\text { upon ultrasound treatment } \\
\text { showed efficacy in the } \\
\text { treatment of multidrug } \\
\text { resistant cancer cells. This } \\
\text { system may transport other } \\
\text { chemotherapeutic agents in } \\
\text { the future. }\end{array}$ & \multirow[t]{3}{*}[103,104,124]{} \\
\hline & & $\begin{array}{l}\text { Purified exosomes from } \\
\text { immature DCs (imDCs) } \\
\text { loaded with doxorubicin } \\
\text { (Dox) via electroporation, } \\
\text { showed highly efficient } \\
\text { targeting and Dox delivery to } \\
\alpha v \text { integrin-positive breast } \\
\text { cancer cells }\end{array}$ & \\
\hline & & $\begin{array}{l}\text { Therapeutic strategy of } \\
\text { codelivering genes and } \\
\text { chemotherapeutic drugs, } \\
\text { A15-Exosomes coloaded with } \\
\text { Doxorubicin and Cho-miR159 } \\
\text { induced synergistic } \\
\text { therapeutic effects in } \\
\text { MDA-MB-231 cells by } \\
\text { effectively silenced the TCF-7 } \\
\text { gene improving anticancer } \\
\text { effects, without adverse effects }\end{array}$ & \\
\hline
\end{tabular}

Legend: HER2, Erb-B2 Receptor Tyrosine Kinase 2; CD4, T-Cell Surface Glycoprotein CD4; HSP60, Heat Shock Protein 60; HSP90, Heat Shock Protein 90; MHC I, Class I Major Histocompatibility Complex; MHC II, Class II Major Histocompatibility Complex; CD40, CD40 Molecule; CD86, CD86 Molecule; RANTES, Regulated upon Activation, Normal T Cell Expressed and Presumably Secreted; IL-1 $\beta$, Interleukin 1 Beta; NKG2D, Receptor natural killer group 2, member D; CD90, CD90 molecule; CD40L, CD40 molecule ligand; CTL, Cytotoxic T cells; KRAS, KRAS Proto-Oncogene, GTPase; siRNA, small interfering RNA.

Cancer-derived exosomes transport mRNAs, receptors for pathological growth factor and soluble or membrane proteins with immune checkpoint activity such as HLA-G, to support tumor spread and survival. Increased levels of exosomes in liquid biopsies of cancer patients are associated with chemotaxis and chemotherapy resistance acquisition by 
cancer cells increasing an active drug efflux. The above highlights the importance of finding exosomes release inhibitors to improve the antitumor effect of chemotherapy [125-127]. exosome and microvesicles release inhibitors such as Chloramidine/Bisindolylmaleimide, and inhibitors of neutral sphingomyelinase like GW4869, proved to be effective to enhance cancer chemotherapy efficacy $[126,128,129]$. However, exosome release inhibition by cannabidiol was more potent than $\mathrm{Cl}$-amidine alone, but when were administered in combination, the inhibitory effect is significantly higher [130], suggesting that the anticancer activity of CBD may partly be due to its regulatory effects on the biogenesis and release of exosomes and micro vesicles by cancer cells, and that may have a clinical application to increase the efficacy of cancer chemotherapy.

\section{Conclusions}

For many decades, cancer studies focused on the tumor cell without taking into account the participation of other actors involved in carcinogenesis, such as the immune infiltrate, the population of normal cells within the tumor and extracellular vesicles [131]. The majority of nucleated cells secrete exosomes which participate in numerous biological cell processes in biological fluids. However, under pathological conditions, they can be involved in tumor development. Exosomes transport proteins, nucleic acids, lipids and different RNA species, especially noncoding RNA, capable of modulating gene expression in target cells (Figure 2). The immune system functions as a switch that turns on and off cell activity, stimulating the repression of cytotoxic T-cell functions or stimulating the proliferation and effector functions of regulatory cells. More and more studies have found that exosomes transmit biological information by transporting different RNA species, proteins, metabolites and other substances and, therefore, they could exert biological and therapeutic effects [132]. Although the therapeutic potential of exosomes has not been widely explored, innovative strategies aimed to inhibit tumor progression could contemplate systemic exosome depletion, and others are developing exosome-loaded drug delivery systems that may be applicable shortly [66].

In our review, we exposed some examples of how tumor-associated exosomes are involved in angiogenesis and in the epithelial-mesenchymal transition, the involvement of noncoding RNA and proteins contained in exosomes, and the potential use of these vesicles as a weapon to fight against this disease. Understanding the biology of exosomes may have significant implications for the diagnosis, prognosis and treatment of cancer, with great potential as biomarkers of this disease.

Funding: This research was funded by Instituto Nacional de Cancerología Grant Number XRPM: C19010300-454, (to Rodriguez J.A.), Colombian Sciences Ministry scholarship (to Rincon-Riveros A.), and small grant of Universidad del Rosario, Bogotá (to Villegas V.E.).

Institutional Review Board Statement: Not applicable.

Informed Consent Statement: Not applicable.

Data Availability Statement: No new data were created or analyzed in this study. Data sharing is not applicable to this article.

Conflicts of Interest: The authors declare no conflict of interest. 


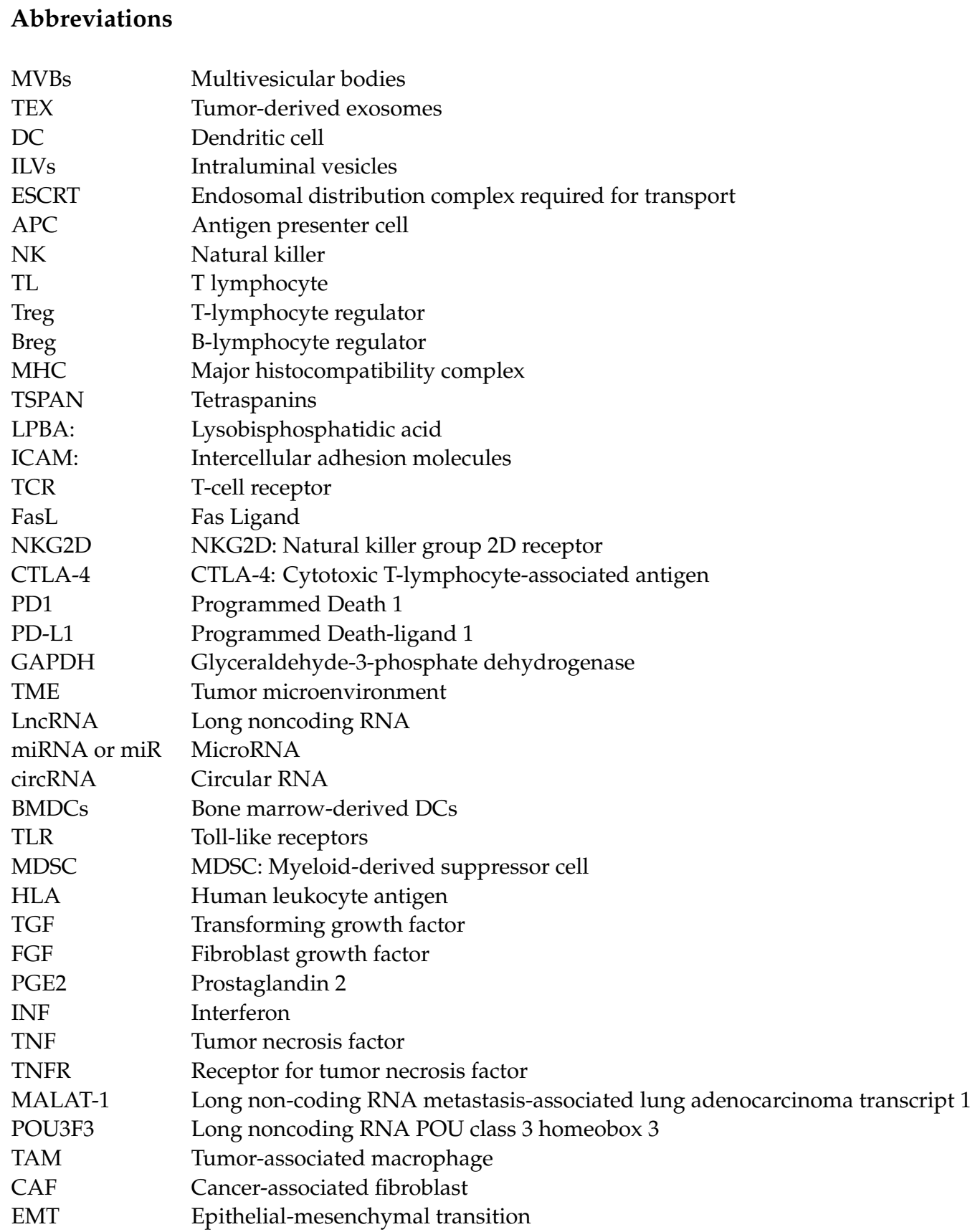

\section{References}

1. Mathivanan, S.; Ji, H.; Simpson, R.J. Exosomes: Extracellular organelles important in intercellular communication. J. Proteom. 2010, 73, 1907-1920. [CrossRef] [PubMed]

2. Théry, C.; Zitvogel, L.; Amigorena, S. Exosomes: Composition, biogenesis and function. Nat. Rev. Immunol. 2002, 2, 569-579. [CrossRef] [PubMed]

3. Raposo, G.; Stoorvogel, W. Extracellular vesicles: Exosomes, microvesicles, and friends. J. Cell Biol. 2013, 200, 373-383. [CrossRef] [PubMed]

4. Marote, A.; Teixeira, F.G.; Mendes-Pinheiro, B.; Salgado, A.J. MSCs-Derived Exosomes: Cell-Secreted Nanovesicles with Regenerative Potential. Front. Pharmacol. 2016, 7, 231. [CrossRef]

5. Ge, R.; Tan, E.; Sharghi-Namini, S.; Asada, H.H. Exosomes in Cancer Microenvironment and Beyond: Have we Overlooked these Extracellular Messengers? Cancer Microenviron. 2012, 5, 323-332. [CrossRef] [PubMed]

6. Lindenbergh, M.F.; Stoorvogel, W. Antigen Presentation by Extracellular Vesicles from Professional Antigen-Presenting Cells Annu. Rev. Immunol. 2018, 36, 435-459. [CrossRef]

7. Edgar, J.R.; Manna, P.T.; Nishimura, S.; Banting, G.; Robinson, M.S. Tetherin is an exosomal tether. eLife 2016, 5, e17180. [CrossRef]

8. Swann, J.B.; Smyth, M.J. Immune surveillance of tumors. J. Clin. Investig. 2007, 117, 1137-1146. [CrossRef] 
9. Morvan, J.; Rinaldi, B.; Friant, S. Pkh1/2-dependent phosphorylation of Vps27 regulates ESCRT-I recruitment to endosomes. Mol. Biol. Cell 2012, 23, 4054-4064. [CrossRef]

10. Raposo, G.; Marks, M.S. Melanosomes-Dark organelles enlighten endosomal membrane transport. Nat. Rev. Mol. Cell Biol. 2007, 8, 786-797. [CrossRef]

11. Buschow, S.I.; Hoen, E.N.N.; Van Niel, G.; Pols, M.S.; Broeke, T.T.; Lauwen, M.; Ossendorp, F.; Melief, C.J.M.; Raposo, G.; Wubbolts, R.; et al. MHC II in Dendritic Cells is Targeted to Lysosomes or T Cell-Induced Exosomes Via Distinct Multivesicular Body Pathways. Traffic 2009, 10, 1528-1542. [CrossRef] [PubMed]

12. Trajkovic, K.; Hsu, C.; Chiantia, S.; Rajendran, L.; Wenzel, D.; Wieland, F.; Schwille, P.; Brügger, B.; Simons, M. Ceramide Triggers Budding of Exosome Vesicles into Multivesicular Endosomes. Science 2008, 319, 1244-1247. [CrossRef] [PubMed]

13. Skotland, T.; Sandvig, K.; Llorente, A. Lipids in exosomes: Current knowledge and the way forward. Prog. Lipid Res. 2017, 66, 30-41. [CrossRef] [PubMed]

14. Baietti, M.F.; Zhang, Z.; Mortier, E.; Melchior, A.; Degeest, G.; Geeraerts, A.; Ivarsson, Y.; Depoortere, F.; Coomans, C.; Vermeiren, E.; et al. Syndecan-syntenin-ALIX regulates the biogenesis of exosomes. Nat. Cell Biol. 2012, 14, 677. [CrossRef]

15. Henne, W.M.; Buchkovich, N.J.; Emr, S. The ESCRT Pathway. Dev. Cell 2011, 21, 77-91. [CrossRef]

16. Stuffers, S.; Wegner, C.S.; Stenmark, H.; Brech, A. Multivesicular endosome biogenesis in the absence of ESCRTs. Traffic 2009, 10, 925-937. [CrossRef]

17. Henne, W.M.; Stenmark, H.; Emr, S.D. Molecular Mechanisms of the Membrane Sculpting ESCRT Pathway. Cold Spring Harb. Perspect. Biol. 2013, 5, a016766. [CrossRef]

18. Mathivanan, S.; Fahner, C.J.; Reid, G.E.; Simpson, R.J. ExoCarta 2012: Database of exosomal proteins, RNA and lipids. Nucleic Acids Res. 2011, 40, D1241-D1244. [CrossRef]

19. Ostrowski, M.; Carmo, N.B.; Krumeich, S.; Fanget, I.; Raposo, G.; Savina, A.; Moita, C.F.; Schauer, K.; Hume, A.N.; Freitas, R.P.; et al. Rab27a and Rab27b control different steps of the exosome secretion pathway. Nat. Cell Biol. 2009, 12, 19-30. [CrossRef]

20. Gastpar, R.; Gehrmann, M.; Bausero, M.A.; Asea, A.; Gross, C.; Schroeder, J.A.; Multhoff, G. Heat Shock Protein 70 Surface-Positive Tumor Exosomes Stimulate Migratory and Cytolytic Activity of Natural Killer Cells. Cancer Res. 2005, 65, 5238-5247. [CrossRef]

21. Raposo, G.; Nijman, H.W.; Stoorvogel, W.; Liejendekker, R.; Harding, C.V.; Melief, C.J.; Geuze, H.J. B lymphocytes secrete antigen-presenting vesicles. J. Exp. Med. 1996, 183, 1161-1172. [CrossRef] [PubMed]

22. Yang, Y.; Han, Q.; Hou, Z.; Zhang, C.; Tian, Z.; Zhang, J. Exosomes mediate hepatitis B virus (HBV) transmission and NK-cell dysfunction. Cell. Mol. Immunol. 2017, 14, 465-475. [CrossRef] [PubMed]

23. Azmi, A.S.; Bao, B.; Sarkar, F.H. Exosomes in cancer development, metastasis, and drug resistance: A comprehensive review. Cancer Metastasis Rev. 2013, 32, 623-642. [CrossRef] [PubMed]

24. Lin, J.; Liu, J.; Huang, B.; Chen, X.; Chen, X.-M.; Xu, Y.-M.; Huang, L.-F.; Wang, X.-Z. Exosomes: Novel Biomarkers for Clinical Diagnosis. Sci. World J. 2015, 2015, 1-8. [CrossRef]

25. Hoen, E.N.M.N.-T.; Buschow, S.I.; Anderton, S.M.; Stoorvogel, W.; Wauben, M.H. Activated T cells recruit exosomes secreted by dendritic cells via LFA-1. Blood 2009, 113, 1977-1981. [CrossRef]

26. Muturi, H.T.; Dreesen, J.D.; Nilewski, E.; Jastrow, H.; Giebel, B.; Ergun, S.; Singer, B.B. Tumor and Endothelial Cell-Derived Microvesicles Carry Distinct CEACAMs and Influence T-Cell Behavior. PLoS ONE 2013, 8, e74654. [CrossRef]

27. Leone, D.A.; Peschel, A.; Brown, M.; Schachner, H.; Ball, M.J.; Gyuraszova, M.; Salzer-Muhar, U.; Fukuda, M.; Vizzardelli, C.; Bohle, B.; et al. Surface LAMP-2 Is an Endocytic Receptor That Diverts Antigen Internalized by Human Dendritic Cells into Highly Immunogenic Exosomes. J. Immunol. 2017, 199, 531-546. [CrossRef]

28. Bissig, C.; Lenoir, M.; Velluz, M.C.; Kufareva, I.; Abagyan, R.; Overduin, M.; Gruenberg, J. Viral infection controlled by a calci-um-dependent lipid-binding module in ALIX. Dev. Cell 2013, 25, 364-373. [CrossRef]

29. Théry, C.; Duban, L.; Segura, E.; Véron, P.; Lantz, O.; Amigorena, S. Indirect activation of naïve CD4+ T cells by dendritic cell-derived exosomes. Nat. Immunol. 2002, 3, 1156-1162. [CrossRef]

30. Zitvogel, L.; Regnault, A.; Lozier, A.; Wolfers, J.; Flament, C.; Tenza, D.; Ricciardi-Castagnoli, P.; Raposo, G.; Amigorena, S. Eradication of established murine tumors using a novel cell-free vaccine: Dendritic cell derived exosomes. Nat. Med. 1998, 4, 594-600. [CrossRef]

31. André, F.; Chaput, N.; Schartz, N.E.C.; Flament, C.; Aubert, N.; Bernard, J.; Lemonnier, F.; Raposo, G.; Escudier, B.; Hsu, D.-H.; et al. Exosomes as Potent Cell-Free Peptide-Based Vaccine. I. Dendritic Cell-Derived Exosomes Transfer Functional MHC Class I/Peptide Complexes to Dendritic Cells. J. Immunol. 2004, 172, 2126-2136. [CrossRef] [PubMed]

32. Segura, E.; Nicco, C.; Lombard, B.; Veéron, P.; Raposo, G.; Batteux, F.; Amigorena, S.; Theéry, C. ICAM-1 on exosomes from mature dendritic cells is critical for efficient naive T-cell priming. Blood 2005, 106, 216-223. [CrossRef] [PubMed]

33. Segura, E.; Amigorena, S.; Théry, C. Mature dendritic cells secrete exosomes with strong ability to induce antigen-specific effector immune responses. Blood Cells Mol. Dis. 2005, 35, 89-93. [CrossRef] [PubMed]

34. Clayton, A.; Mitchell, J.P.; Court, J.; Linnane, S.; Mason, M.D.; Tabi, Z. Human Tumor-Derived Exosomes Down-Modulate NKG2D Expression. J. Immunol. 2008, 180, 7249-7258. [CrossRef] [PubMed]

35. Yang, X.; Meng, S.; Jiang, H.; Zhu, C.; Wu, W. Exosomes Derived from Immature Bone Marrow Dendritic Cells Induce Tolerogenicity of Intestinal Transplantation in Rats. J. Surg. Res. 2011, 171, 826-832. [CrossRef] [PubMed] 
36. Njock, M.-S.; Cheng, H.S.; Dang, L.T.; Nazari-Jahantigh, M.; Lau, A.C.; Boudreau, E.; Roufaiel, M.; Cybulsky, M.I.; Schober, A.; Fish, J.E. Endothelial cells suppress monocyte activation through secretion of extracellular vesicles containing antiinflammatory microRNAs. Blood 2015, 125, 3202-3212. [CrossRef]

37. Escudero-Hernández, C.; Plaza-Izurieta, L.; Garrote, J.A.; Bilbao, J.R.; Arranz, E. Association of the IL-15 and IL-15R $\alpha$ genes with celiac disease. Cytokine 2017, 99, 73-79. [CrossRef]

38. Viaud, S.; Terme, M.; Flament, C.; Taieb, J.; André, F.; Novault, S.; Escudier, B.; Robert, C.; Caillat-Zucman, S.; Tursz, T.; et al. Dendritic Cell-Derived Exosomes Promote Natural Killer Cell Activation and Proliferation: A Role for NKG2D Ligands and IL-15R $\alpha$. PLoS ONE 2009, 4, e4942. [CrossRef]

39. Hao, S.; Bai, O.; Li, F.; Yuan, J.; Laferte, S.; Xiang, J. Mature dendritic cells pulsed with exosomes stimulate efficient cytotoxic T-lymphocyte responses and antitumour immunity. Immunology 2007, 120, 90-102. [CrossRef]

40. Berchem, G.; Noman, M.Z.; Bosseler, M.; Paggetti, J.; Baconnais, S.; Le Cam, E.; Nanbakhsh, A.; Moussay, E.; Mami-Chouaib, F.; Janji, B.; et al. Hypoxic tumor-derived microvesicles negatively regulate NK cell function by a mechanism involving TGF- $\beta$ and miR23a transfer. OncoImmunology 2016, 5, e1062968. [CrossRef]

41. Fabbri, M.; Paone, A.; Calore, F.; Galli, R.; Gaudio, E.; Santhanam, R.; Lovat, F.; Fadda, P.; Mao, C.; Nuovo, G.J.; et al. MicroRNAs bind to Toll-like receptors to induce prometastatic inflammatory response. Proc. Natl. Acad. Sci. USA 2012, 109, E2110-E2116. [CrossRef] [PubMed]

42. Whiteside, T.L. Immune modulation of T-cell and NK (natural killer) cell activities by TEXs (tumour-derived exosomes). Biochem. Soc. Trans. 2013, 41, 245-251. [CrossRef] [PubMed]

43. Liu, J.; Wu, S.; Zheng, X.; Zheng, P.; Fu, Y.; Wu, C.; Lu, B.; Ju, J.; Jiang, J. Immune suppressed tumor microenvironment by exosomes derived from gastric cancer cells via modulating immune functions. Sci. Rep. 2020, 10, 1-12. [CrossRef] [PubMed]

44. Whiteside, T.L. Exosomes and tumor-mediated immune suppression. J. Clin. Investig. 2016, 126, 1216-1223. [CrossRef]

45. Valenti, R.; Huber, V.; Filipazzi, P.; Pilla, L.; Sovena, G.; Villa, A.; Corbelli, A.; Fais, S.; Parmiani, G.; Rivoltini, L. Human Tumor-Released Microvesicles Promote the Differentiation of Myeloid Cells with Transforming Growth Factor- $\beta$-Mediated Suppressive Activity on T Lymphocytes. Cancer Res. 2006, 66, 9290-9298. [CrossRef]

46. Yu, S.; Liu, C.; Su, K.; Wang, J.; Liu, Y.; Zhang, L.; Li, C.; Cong, Y.; Kimberly, R.; Grizzle, W.E.; et al. Tumor Exosomes Inhibit Differentiation of Bone Marrow Dendritic Cells. J. Immunol. 2007, 178, 6867-6875. [CrossRef]

47. Zhou, M.; Chen, J.; Zhou, L.; Chen, W.; Ding, G.; Cao, L. Pancreatic cancer derived exosomes regulate the expression of TLR4 in dendritic cells via miR-203. Cell. Immunol. 2014, 292, 65-69. [CrossRef]

48. Whiteside, T.L. (Ed.) Immune suppression in cancer: Effects on immune cells, mechanisms and future therapeutic intervention. In Seminars in Cancer Biology; Elsevier: Amsterdam, The Netherlands, 2006.

49. Szajnik, M.; Czystowska, M.; Szczepanski, M.J.; Mandapathil, M.; Whiteside, T.L. Tumor-Derived Microvesicles Induce, Expand and Up-Regulate Biological Activities of Human Regulatory T Cells (Treg). PLoS ONE 2010, 5, e11469. [CrossRef]

50. Muller, L.; Mitsuhashi, M.; Simms, P.; Gooding, W.E.; Whiteside, T.L. Tumor-derived exosomes regulate expression of immune function-related genes in human T cell subsets. Sci. Rep. 2016, 6, 20254. [CrossRef]

51. Clayton, A.; Al-Taei, S.; Webber, J.; Mason, M.D.; Tabi, Z. Cancer Exosomes Express CD39 and CD73, Which Suppress T Cells through Adenosine Production. J. Immunol. 2011, 187, 676-683. [CrossRef]

52. Schuler, P.J.; Saze, Z.; Hong, C.-S.; Muller, L.; Gillespie, D.G.; Cheng, D.; Harasymczuk, M.; Mandapathil, M.; Lang, S.; Jackson, E.K.; et al. Human CD4+CD39+regulatory T cells produce adenosine upon co-expression of surface CD73 or contact with CD73+exosomes or CD73+cells. Clin. Exp. Immunol. 2014, 177, 531-543. [CrossRef] [PubMed]

53. Allard, B.; Longhi, M.S.; Robson, S.C.; Stagg, J. The ectonucleotidases CD39 and CD73: Novel checkpoint inhibitor targets. Immunol. Rev. 2017, 276, 121-144. [CrossRef] [PubMed]

54. Fang, T.; Lv, H.; Lv, G.; Li, T.; Wang, C.; Han, Q.; Yu, L.; Su, B.; Guo, L.; Huang, S.; et al. Tumor-derived exosomal miR-1247-3p induces cancer-associated fibroblast activation to foster lung metastasis of liver cancer. Nat. Commun. 2018, 9, 191. [CrossRef] [PubMed]

55. Zhang, Y.; Li, M.; Hu, C. Exosomal transfer of miR-214 mediates gefitinib resistance in non-small cell lung cancer. Biochem. Biophys. Res. Commun. 2018, 507, 457-464. [CrossRef] [PubMed]

56. Rosser, E.C.; Mauri, C. Regulatory B Cells: Origin, Phenotype, and Function. Immun. 2015, 42, 607-612. [CrossRef]

57. Sherwood, L.M.; Parris, E.E.; Folkman, J. Tumor Angiogenesis: Therapeutic Implications. N. Engl. J. Med. 1971, 285, 1182-1186. [CrossRef] [PubMed]

58. Maia, J.; Caja, S.; Strano Moraes, M.C.; Couto, N.; Costa-Silva, B. Exosome-Based Cell-Cell Communication in the Tumor Micro-environment. Front. Cell Dev. Biol. 2018, 6, 18. [CrossRef]

59. Li, Y.; An, J.; Huang, S.; He, J.; Zhang, J. Esophageal cancer-derived microvesicles induce regulatory B cells. Cell Biochem. Funct. 2015, 33, 308-313. [CrossRef]

60. Yang, C.; Chalasani, G.; Ng, Y.-H.; Robbins, P.D. Exosomes released from mycoplasma infected tumor cells activate inhibitory B cells. PLoS ONE 2012, 7, e36138. [CrossRef]

61. Menck, K.; Klemm, F.; Gross, J.C.; Pukrop, T.; Wenzel, D.; Binder, C. Induction and transport of Wnt 5a during macrophageinduced malignant invasion is mediated by two types of extracellular vesicles. Oncotarget 2013, 4, 2057-2066. [CrossRef] 
62. Wu, Q.; Wu, X.; Ying, X.; Zhu, Q.; Wang, X.; Jiang, L.; Chen, X.; Wu, Y.; Wang, X. Suppression of endothelial cell migration by tumor associated macrophage-derived exosomes is reversed by epithelial ovarian cancer exosomal lncRNA. Cancer Cell Int. 2017, 17, 1-13. [CrossRef]

63. Zheng, P.; Chen, L.; Yuan, X.; Luo, Q.; Liu, Y.; Xie, G.; Ma, Y.; Shen, L. Exosomal transfer of tumor-associated macrophage-derived miR-21 confers cisplatin resistance in gastric cancer cells. J. Exp. Clin. Cancer Res. 2017, 36, 53. [CrossRef] [PubMed]

64. Kalluri, R. The biology and function of fibroblasts in cancer. Nat. Rev. Cancer 2016, 16, 582-598. [CrossRef] [PubMed]

65. Kalluri, R.; Zeisberg, M. Fibroblasts in cancer. Nat. Rev. Cancer 2006, 6, 392-401. [CrossRef] [PubMed]

66. Huang, T.-X.; Guan, X.-Y.; Fu, L. Therapeutic targeting of the crosstalk between cancer-associated fibroblasts and cancer stem cells. Am. J. Cancer Res 2019, 9, 1889-1904.

67. Herrera, M.; Galindo-Pumariño, C.; García-Barberán, V.; Peña, C. A Snapshot of The Tumor Microenvironment in Colorectal Cancer: The Liquid Biopsy. Int. J. Mol. Sci. 2019, 20, 6016. [CrossRef]

68. $\mathrm{Hu}, \mathrm{T}$.; $\mathrm{Hu}, \mathrm{J}$. Melanoma-derived exosomes induce reprogramming fibroblasts into cancer-associated fibroblasts via $\mathrm{Gm} 26809$ delivery. Cell Cycle 2019, 18, 3085-3094. [CrossRef]

69. Feng, W.; Dean, D.C.; Hornicek, F.J.; Shi, H.; Duan, Z. Exosomes promote pre-metastatic niche formation in ovarian cancer. Mol. Cancer 2019, 18, 1-11. [CrossRef]

70. Lamouille, S.; Xu, J.; Derynck, R. Molecular mechanisms of epithelial-mesenchymal transition. Nat. Rev. Mol. Cell Biol. 2014, 15, 178-196. [CrossRef]

71. Dongre, A.; Weinberg, R.A. New insights into the mechanisms of epithelial-mesenchymal transition and implications for cancer. Nat. Rev. Mol. Cell Biol. 2019, 20, 69-84. [CrossRef]

72. Han, S.-H.; Kim, H.J.; Gwak, J.M.; Kim, M.; Chung, Y.R.; Park, S.Y. MicroRNA-222 Expression as a Predictive Marker for Tumor Progression in Hormone Receptor-Positive Breast Cancer. J. Breast Cancer 2017, 20, 35-44. [CrossRef] [PubMed]

73. Hu, Y.; Qi, C.; Liu, X.; Zhang, C.; Gao, J.; Wu, Y.; Yang, J.; Zhao, Q.; Li, J.; Wang, X.; et al. Malignant ascites-derived exosomes promote peritoneal tumor cell dissemination and reveal a distinct miRNA signature in advanced gastric cancer. Cancer Lett. 2019, 457, 142-150. [CrossRef]

74. Katoh, M. Therapeutics targeting angiogenesis: Genetics and epigenetics, extracellular miRNAs and signaling networks (Review). Int. J. Mol. Med. 2013, 32, 763-767. [CrossRef]

75. Conigliaro, A.; Costa, V.; Dico, A.L.; Saieva, L.; Buccheri, S.; Dieli, F.; Manno, M.; Raccosta, S.; Mancone, C.; Tripodi, M.; et al. CD90+ liver cancer cells modulate endothelial cell phenotype through the release of exosomes containing H19 lncRNA. Mol. Cancer 2015, 14, 155. [CrossRef] [PubMed]

76. Guo, H.; Wu, L.; Yang, Q.; Ye, M.; Zhu, X. Functional linc-POU3F3 is overexpressed and contributes to tumorigenesis in glioma. Gene 2015, 554, 114-119. [CrossRef]

77. Shan, T.-D.; Xu, J.-H.; Yu, T.; Lin-Na, Z.; Zhao, L.-N.; Ouyang, H.; Luo, S.; Lu, X.-J.; Huang, C.-Z.; Lan, Q.-S.; et al. Knockdown of linc-POU3F3 suppresses the proliferation, apoptosis, and migration resistance of colorectal cancer. Oncotarget 2016, 7, 961-975. [CrossRef] [PubMed]

78. Qiu, J.-J.; Lin, X.-J.; Tang, X.-Y.; Zheng, T.-T.; Lin, Y.-Y.; Hua, K.-Q. Exosomal Metastasis-Associated Lung Adenocarcinoma Transcript 1 Promotes Angiogenesis and Predicts Poor Prognosis in Epithelial Ovarian Cancer. Int. J. Biol. Sci. 2018, 14, 1960-1973. [CrossRef]

79. Zhou, Z.; Zhang, H.; Deng, T.; Ning, T.; Liu, R.; Liu, D.; Bai, M.; Ying, G.; Ba, Y. Exosomes Carrying MicroRNA-155 Target Forkhead Box O3 of Endothelial Cells and Promote Angiogenesis in Gastric Cancer. Mol. Ther. Oncolytics 2019, 15, $223-233$. [CrossRef]

80. Deng, T.; Zhang, H.; Yang, H.; Wang, H.; Bai, M.; Sun, W.; Wang, X.; Si, Y.; Ning, T.; Zhang, L.; et al. Exosome miR-155 Derived from Gastric Carcinoma Promotes Angiogenesis by Targeting the c-MYB/VEGF Axis of Endothelial Cells. Mol. Ther. Nucleic Acids 2020, 19, 1449-1459. [CrossRef]

81. Duan, B.; Shi, S.; Yue, H.; You, B.; Shan, Y.; Zhu, Z.; Bao, L.; You, Y. Exosomal miR-17-5p promotes angiogenesis in nasopharyngeal carcinoma via targeting BAMBI. J. Cancer 2019, 10, 6681-6692. [CrossRef]

82. Bao, L.; You, B.; Shi, S.; Shan, Y.; Zhang, Q.; Yue, H.; Zhang, J.; Zhang, W.; Shi, Y.; Liu, Y.; et al. Metastasis-associated miR-23a from nasopharyngeal carcinoma-derived exosomes mediates angiogenesis by repressing a novel target gene TSGA10. Oncogene 2018, 37, 2873-2889. [CrossRef] [PubMed]

83. Zhou, X.; Yan, T.; Huang, C.; Xu, Z.; Wang, L.; Jiang, E.; Wang, H.; Chen, Y.; Liu, K.; Shao, Z.; et al. Melanoma cell-secreted exosomal miR-155-5p induce proangiogenic switch of cancer-associated fibroblasts via SOCS1/JAK2/STAT3 signaling pathway. J. Exp. Clin. Cancer Res. 2018, 37, 1-15. [CrossRef] [PubMed]

84. He, L.; Zhu, W.; Chen, Q.; Yuan, Y.; Wang, Y.; Wang, J.; Wu, X. Ovarian cancer cell-secreted exosomal miR-205 promotes metastasis by inducing angiogenesis. Theranostics 2019, 9, 8206-8220. [CrossRef]

85. Kim, D.H.; Park, Y.R.; Kim, H.; Choi, Y.J.; Kim, S.Y.; Sung, K.J.; Sung, Y.H.; Choi, C.-M.; Yun, M.; Yi, Y.-S.; et al. Tumor-derived exosomal miR-619-5p promotes tumor angiogenesis and metastasis through the inhibition of RCAN1.4. Cancer Lett. 2020, 475, 2-13. [CrossRef] [PubMed]

86. Cheng, C.; Zhang, Z.; Cheng, F.; Shao, Z. Exosomal lncRNA RAMP2-AS1 Derived from Chondrosarcoma Cells Promotes Angiogenesis Through miR-2355-5p/VEGFR2 Axis. OncoTargets Ther. 2020, 13, 3291-3301. [CrossRef] 
87. Wang, J.; Guan, X.; Zhang, Y.; Ge, S.; Zhang, L.; Li, H.; Wang, X.; Liu, R.; Ning, T.; Deng, T.; et al. Exosomal miR-27a Derived from Gastric Cancer Cells Regulates the Transformation of Fibroblasts into Cancer-Associated Fibroblasts. Cell. Physiol. Biochem. 2018, 49, 869-883. [CrossRef]

88. Li, Y.-Y.; Tao, Y.-W.; Gao, S.; Li, P.; Zheng, J.-M.; Zhang, S.-E.; Liang, J.; Zhang, Y. Cancer-associated fibroblasts contribute to oral cancer cells proliferation and metastasis via exosome-mediated paracrine miR-34a-5p. EBioMedicine 2018, 36, 209-220. [CrossRef]

89. Wang, H.; Wei, H.; Wang, J.; Li, L.; Chen, A.; Li, Z. MicroRNA-181d-5p-Containing Exosomes Derived from CAFs Promote EMT by Regulating CDX2/HOXA5 in Breast Cancer. Mol. Ther. Nucleic Acids 2020, 19, 654-667. [CrossRef]

90. Qu, Z.; Feng, J.; Pan, H.; Jiang, Y.; Duan, Y.; Fa, Z. Exosomes derived from HCC cells with different invasion characteristics mediated EMT through TGF- $\beta$ /Smad signaling pathway. OncoTargets Ther. 2019, 12, 6897-6905. [CrossRef]

91. Li, Y.; Zhang, X.; Zheng, Q.; Zhang, Y.; Ma, Y.; Zhu, C.; Yang, L.; Peng, X.; Wang, Q.; Wang, B.; et al. YAP1 Inhibition in HUVECs Is Associated with Released Exosomes and Increased Hepatocarcinoma Invasion and Metastasis. Mol. Ther. Nucleic Acids 2020 21, 86-97. [CrossRef]

92. Liang, Z.-X.; Liu, H.-S.; Wang, F.-W.; Xiong, L.; Zhou, C.; Hu, T.; He, X.-W.; Wu, X.-J.; Xie, D.; Wu, X.; et al. LncRNA RPPH1 promotes colorectal cancer metastasis by interacting with TUBB3 and by promoting exosomes-mediated macrophage M2 polarization. Cell Death Dis. 2019, 10, 829. [CrossRef] [PubMed]

93. He, S.; Li, Z.; Yu, Y.; Zeng, Q.; Cheng, Y.; Ji, W.; Xia, W.; Lu, S. Exosomal miR-499a-5p promotes cell proliferation, migration and EMT via mTOR signaling pathway in lung adenocarcinoma. Exp. Cell Res. 2019, 379, 203-213. [CrossRef] [PubMed]

94. Qian, M.; Wang, S.; Guo, X.; Wang, J.; Zhang, Z.; Qiu, W.; Gao, X.; Chen, Z.; Xu, J.; Zhao, R.; et al. Hypoxic glioma-derived exosomes deliver microRNA-1246 to induce M2 macrophage polarization by targeting TERF2IP via the STAT3 and NF- $\mathrm{KB}$ pathways. Oncogene 2020, 39, 428-442. [CrossRef]

95. Li, Y.-L.; Wu, L.-W.; Zeng, L.-H.; Zhang, Z.-Y.; Wang, W.; Zhang, C.; Lin, N.-M. ApoC1 promotes the metastasis of clear cell renal cell carcinoma via activation of STAT3. Oncogene 2020, 39, 6203-6217. [CrossRef] [PubMed]

96. Naseri, M.; Bozorgmehr, M.; Zöller, M.; Pirmardan, E.R.; Madjd, Z. Tumor-derived exosomes: The next generation of promising cell-free vaccines in cancer immunotherapy. OncoImmunology 2020, 9, 1779991. [CrossRef] [PubMed]

97. Shi, J.; Zhang, Y.; Yao, B.; Sun, P.; Hao, Y.; Piao, H.; Zhao, X. Role of Exosomes in the Progression, Diagnosis, and Treatment of Gliomas. Med Sci. Monit. 2020, 26, e924023-1. [CrossRef]

98. Mughees, M.; Kumar, K.; Wajid, S. Exosome vesicle as a nano-therapeutic carrier for breast cancer. J. Drug Target. 2020, 1-28. [CrossRef]

99. Xu, Z.; Zeng, S.; Gong, Z.; Yan, Y. Exosome-based immunotherapy: A promising approach for cancer treatment. Mol. Cancer 2020, 19, 1-16. [CrossRef]

100. Liao, W.; Du, Y.; Zhang, C.; Pan, F.; Yao, Y.; Zhang, T.; Peng, Q. Exosomes: The next generation of endogenous nanomaterials for advanced drug delivery and therapy. Acta Biomater. 2019, 86, 1-14. [CrossRef]

101. Zhu, X.; Badawi, M.; Pomeroy, S.; Sutaria, D.S.; Xie, Z.; Baek, A.; Jiang, J.; Elgamal, O.A.; Mohamed, B.; La Perle, K.; et al. Comprehensive toxicity and immunogenicity studies reveal minimal effects in mice following sustained dosing of extracellular vesicles derived from HEK293T cells. J. Extracell. Vesicles 2017, 6, 1324730. [CrossRef]

102. Kalluri, R.; LeBleu, V.S. The biology, function, and biomedical applications of exosomes. Science 2020, 367, eaau6977. [CrossRef] [PubMed]

103. Tian, Y.; Li, S.; Song, J.; Ji, T.; Zhu, M.; Anderson, G.J.; Wei, J.; Nie, G. A doxorubicin delivery platform using engineered natural membrane vesicle exosomes for targeted tumor therapy. Biomaterials 2014, 35, 2383-2390. [CrossRef] [PubMed]

104. Kim, M.S.; Haney, M.J.; Zhao, Y.; Mahajan, V.; Deygen, I.; Klyachko, N.L.; Inskoe, E.; Piroyan, A.; Sokolsky, M.; Okolie, O.; et al. Development of exosome-encapsulated paclitaxel to overcome MDR in cancer cells. Nanomed. Nanotechnol. Biol. Med. 2016, 12, 655-664. [CrossRef]

105. Ohno, S.-I.; Takanashi, M.; Sudo, K.; Ueda, S.; Ishikawa, A.; Matsuyama, N.; Fujita, K.; Mizutani, T.; Ohgi, T.; Ochiya, T.; et al. Systemically Injected Exosomes Targeted to EGFR Deliver Antitumor MicroRNA to Breast Cancer Cells. Mol. Ther. 2013, 21, 185-191. [CrossRef] [PubMed]

106. Katakowski, M.; Buller, B.; Zheng, X.; Lu, Y.; Rogers, T.; Osobamiro, O.; Shu, W.; Jiang, F.; Chopp, M. Exosomes from marrow stromal cells expressing miR-146b inhibit glioma growth. Cancer Lett. 2013, 335, 201-204. [CrossRef]

107. Morse, M.A.; Garst, J.; Osada, T.; Khan, S.; Hobeika, A.; Clay, T.M.; Valente, N.; Shreeniwas, R.; Sutton, M.A.; Delcayre, A.; et al. A phase I study of dexosome immunotherapy in patients with advanced non-small cell lung cancer. J. Transl. Med. $2005,3,9$. [CrossRef]

108. Escudier, B.; Dorval, T.; Chaput, N.; André, F.; Caby, M.-P.; Novault, S.; Flament, C.; Leboulaire, C.; Borg, C.; Amigorena, S.; et al. Vaccination of metastatic melanoma patients with autologous dendritic cell (DC) derived-exosomes: Results of thefirst phase I clinical trial. J. Transl. Med. 2005, 3, 10. [CrossRef]

109. Besse, B.; Charrier, M.; Lapierre, V.; Dansin, E.; Lantz, O.; Planchard, D.; Le Chevalier, T.; Livartoski, A.; Barlesi, F.; Laplanche, A.; et al. Dendritic cell-derived exosomes as maintenance immunotherapy after first line chemotherapy in NSCLC. OncoImmunology 2016, 5, e1071008. [CrossRef]

110. Mahaweni, N.M.; Kaijen-Lambers, M.E.; Dekkers, J.; Aerts, J.G.; Hegmans, J.P. Tumour-derived exosomes as antigen delivery carriers in dendritic cell-based immunotherapy for malignant mesothelioma. J. Extracell. Vesicles 2013, 2, 22492. [CrossRef] 
111. Gehrmann, U.; Hiltbrunner, S.; Näslund, T.; Gabrielsson, S. Potentiating antitumor immunity with $\alpha$ GC-loaded exosomes. OncoImmunology 2013, 2, e26261. [CrossRef]

112. Li, R.; Chibbar, R.; Xiang, J. Novel EXO-T vaccine using polyclonal CD4+ T cells armed with HER2-specific exosomes for HER2-positive breast cancer. OncoTargets Ther. 2018, 11, 7089-7093. [CrossRef] [PubMed]

113. Xie, Y.; Wu, J.; Xu, A.; Ahmeqd, S.; Sami, A.; Chibbar, R.; Freywald, A.; Zheng, C.; Xiang, J. Heterologous human/rat HER2-specific exosome-targeted $\mathrm{T}$ cell vaccine stimulates potent humoral and CTL responses leading to enhanced circumvention of HER2 tolerance in double transgenic HLA-A2/HER2 mice. Vaccine 2018, 36, 1414-1422. [CrossRef]

114. Shi, X.; Sun, J.; Li, H.; Lin, H.; Xie, W.; Li, J.; Tan, W.-L. Antitumor efficacy of interferon- $\gamma$-modified exosomal vaccine in prostate cancer. Prostate 2020, 80, 811-823. [CrossRef]

115. Chen, Z.; You, L.; Wang, L.; Huang, X.; Liu, H.; Wei, J.Y.; Zhu, L.; Qian, W. Dual effect of DLBCL-derived EXOs in lymphoma to improve DC vaccine efficacy in vitro while favor tumorgenesis in vivo. J. Exp. Clin. Cancer Res. 2018, 37, 1-18. [CrossRef]

116. Chen, W.; Wang, J.; Shao, C.; Liu, S.; Yu, Y.; Wang, Q.; Cao, X. Efficient induction of antitumor T cell immunity by exosomes derived from heat-shocked lymphoma cells. Eur. J. Immunol. 2006, 36, 1598-1607. [CrossRef]

117. Federici, C.; Shahaj, E.; Cecchetti, S.; Camerini, S.; Casella, M.; Iessi, E.; Camisaschi, C.; Paolino, G.; Calvieri, S.; Ferro, S.; et al. Natural-killer-derived extracellular vesicles: Immune sensors and interactors. Front. Immunol. 2020, 11, 262. [CrossRef]

118. Di Pace, A.L.; Tumino, N.; Besi, F.; Alicata, C.; Conti, L.A.; Munari, E.; Maggi, E.; Vacca, P.; Moretta, L. Characterization of human NK cell-derived exosomes: Role of DNAM1 receptor in exosome-mediated cytotoxicity against tumor. Cancers 2020, $12,661$. [CrossRef]

119. Fu, W.; Lei, C.; Liu, S.; Cui, Y.; Wang, C.; Qian, K.; Li, T.; Shen, Y.; Fan, X.; Lin, F.; et al. CAR exosomes derived from effector CAR-T cells have potent antitumour effects and low toxicity. Nat. Commun. 2019, 10,1-12. [CrossRef]

120. Tang, X.-J.; Sun, X.-Y.; Huang, K.-M.; Zhang, L.; Yang, Z.-S.; Zou, D.-D.; Wang, B.; Warnock, G.L.; Dai, L.-J.; Luo, J. Therapeutic potential of CAR-T cell-derived exosomes: A cell-free modality for targeted cancer therapy. Oncotarget 2015, 6, 44179-44190. [CrossRef]

121. Shi, X.; Cheng, Q.; Hou, T.; Han, M.; Smbatyan, G.; Lang, J.E.; Epstein, A.L.; Lenz, H.-J.; Zhang, Y. Genetically Engineered Cell-Derived Nanoparticles for Targeted Breast Cancer Immunotherapy. Mol. Ther. 2020, 28, 536-547. [CrossRef]

122. Cheng, Q.; Shi, X.; Zhang, Y. Reprogramming Exosomes for Immunotherapy. In Computational Biology; Springer Science and Business Media LLC: Berlin, Germany, 2019; Volume 2097, pp. 197-209.

123. Wu, K.; Xing, F.; Wu, S.-Y.; Watabe, K. Extracellular vesicles as emerging targets in cancer: Recent development from bench to bedside. Biochim. Biophys. Acta (BBA) Bioenerg. 2017, 1868, 538-563. [CrossRef] [PubMed]

124. Gong, C.; Tian, J.; Wang, Z.; Gao, Y.; Wu, X.; Ding, X.; Qiang, L.; Li, G.; Han, Z.; Yuan, Y.; et al. Functional exosomemediated co-delivery of doxorubicin and hydrophobically modified microRNA 159 for triple-negative breast cancer therapy. $J$. Nanobiotechnology 2019, 17, 1-18. [CrossRef] [PubMed]

125. Sung, B.H.; Weaver, A.M. Exosome secretion promotes chemotaxis of cancer cells. Cell Adhes. Migr. 2017, 11, 187-195. [CrossRef] [PubMed]

126. Kosgodage, U.S.; Trindade, R.P.; Thompson, P.R.; Inal, J.; Lange, S. Chloramidine/Bisindolylmaleimide-I-Mediated Inhibition of Exosome and Microvesicle Release and Enhanced Efficacy of Cancer Chemotherapy. Int. J. Mol. Sci. 2017, 18, 1007. [CrossRef] [PubMed]

127. Muralidharan-Chari, V.; Kohan, H.G.; Asimakopoulos, A.G.; Sudha, T.; Sell, S.; Kannan, K.; Boroujerdi, M.; Davis, P.J.; Mousa, S.A. Microvesicle removal of anticancer drugs contributes to drug resistance in human pancreatic cancer cells. Oncotarget 2016, 7, 50365-50379. [CrossRef] [PubMed]

128. Luberto, C.; Hassler, D.F.; Signorelli, P.; Okamoto, Y.; Sawai, H.; Boros, E.; Hazen-Martin, D.J.; Obeid, L.M.; Hannun, Y.A.; Smith, G.K. Inhibition of Tumor Necrosis Factor-induced Cell Death in MCF7 by a Novel Inhibitor of Neutral Sphingo-myelinase. J. Biol. Chem. 2002, 277, 41128-41139. [CrossRef]

129. Catalano, M.; O'Driscoll, L. Inhibiting extracellular vesicles formation and release: A review of EV inhibitors. J. Extracell. Vesicles 2020, 9, 1703244. [CrossRef]

130. Kosgodage, U.S.; Mould, R.; Henley, A.B.; Nunn, A.V.; Guy, G.W.; Thomas, E.L.; Inal, J.M.; Bell, J.D.; Lange, S. Cannabidiol (CBD) Is a Novel Inhibitor for Exosome and Microvesicle (EMV) Release in Cancer. Front. Pharmacol. 2018, 9, 889. [CrossRef]

131. Wu, T.; Dai, Y. Tumor microenvironment and therapeutic response. Cancer Lett. 2017, 387, 61-68. [CrossRef]

132. Yang, X.; Li, Y.; Zou, L.; Zhu, Z. Role of Exosomes in Crosstalk Between Cancer-Associated Fibroblasts and Cancer Cells. Front. Oncol. 2019, 9, 356. [CrossRef] 